\title{
Groundwater discharge from a rock-slope failure system in phyllitic rocks influencing fjord basin hydrodynamics, Stampa in Aurland, western Norway
}

\author{
Helge Henriksen ${ }^{1} \&$ Torbjørn Dale \\ ${ }^{1}$ Faculty of Engineering and Science, Western Norway University of Applied Sciences, Post Box 1336851 Sogndal, Norway. \\ E-mail corresponding author (Helge Henriksen): helge.henriksen@hvl.no
}

This study aims at providing an insight into groundwater recharge and flow in the rock-slope failure system of the Stampa area above the inner part of the Aurlandsfjord. Depending on season and precipitation, the average recharge to groundwater in the fracture system of the unstable slope varies from 0.5 to $16.1 \mathrm{l}$ /s. The small river Joastegrovi, which flows across the back-bounding fracture of the unstable slope, is the main source of recharge. Beneath the back-bounding fracture at c. $900 \mathrm{~m}$ a.s.l. and down towards the Aurlandsfjord, groundwater discharge takes place from six permanent springs and seeps. The total spring discharge varies from 5.9 to $12.5 \mathrm{l} / \mathrm{s}$. Within a rectangular grid of 16 measuring stations in the Aurlandsfjord, directly beneath the unstable mountain slope, vertical profile measurements at $0.3 \mathrm{~m}$ resolution of physical parameters in the seawater indicate the additional presence of several submarine springs and seeps. Groundwater discharging from springs on the fjord bottom has the deepest flow paths and may normally have a residence time of 96-165 days in the fracture network. Groundwater discharging from the mountain slope above the fjord may have flow paths in both the fracture system and in the overlying scree deposits. The recharge/discharge measurements indicate a balance between the total recharge to groundwater in the fracture system and the discharge from springs and seeps. Springs emanating at higher levels than c. $300 \mathrm{~m}$ a.s.l. have not been observed. This indicates that the fracture system is wholly or partly drained above this elevation. The high electrical conductivity of the groundwater indicates ongoing chemical dissolution of minerals in fracture- or foliation planes. It is suspected that abrupt variations in spring discharge and hydraulic heads is caused by widening and narrowing of waterconducting fractures.

Keywords: Unstable rock-slope, fractured rocks, groundwater flow, submarine groundwater discharge, water balance

Received 4. August 2017 / Accepted 28. February 2018 / Published online 9. May 2018

\section{Introduction}

Western Norway has a high concentration of postglacial rock failure systems (Böhme et al., 2011). Some of these have led to large natural disasters mainly caused by their related tsunamis (Furseth, 2006). To prevent future consequences of such disasters, a systematic mapping of unstable rock-slope areas led by the Norwegian Water Resources and Energy Directorate (NVE) and the Geological Survey of Norway (NGU) has been carried out in recent years. A number of detailed site studies, e.g., Böhme et al. (2011), have been conducted.
Most of these, and comparable international studies, rely on geomorphological and structural analysis, often integrated with geomechanical modelling and analysis of displacement measurements. Although water distribution and pressure is an important aspect of hillslope stability, relatively few field studies have been made that integrate water balance and hydrogeology with the other aspects mentioned above. One likely reason for this is that groundwater flow in unstable rock slopes is 'hidden' and extends to great depths with complex flow paths that require long-term monitoring. The potential information that hydrogeological data can have for evaluation of rock-slope stability has been

Henriksen, H. \& Dale, T. 2018: Groundwater discharge from a rock-slope failure system in phyllitic rocks influencing fjord basin hydrodynamics, Stampa in Aurland, western Norway. Norwegian Journal of Geology 98, 55-77. https://dx.doi.org/10.17850/njg98-1-05. 
summarised by Bogaard et al. (2007), mainly based on field studies in the Upper Tinée valley in the southern French Alps (Cappa et al., 2004; Gugliemi et al., 2005; Binet et al., 2007). In Western Norway, Ganerød et al. (2008) discussed the groundwater system of the Åknes rockslide, while Grøneng et al. (2011) addressed the role of meteorological factors on displacements for this rockslide.

This study addresses the water balance and hydrogeology of the northern part of the unstable rock slope Stampa, which is situated in the eastern mountainside above the inner part of the Aurlandsfjord and the Flåm valley in Sogn og Fjordane, western Norway (Fig. 1). The bedrock consists of phyllite, generally considered as a weak rock. Large open cracks and scarps at a plateau in the slope above the fjord are witnesses of recent and ongoing brittle deformation in the area. On the fjord bottom, two deposits from earlier rock avalanches have been mapped and dated to c. 11,000 years BP (before present) and c. 3,000 years BP, respectively (Domaas et al., 2002; Bøe et al., 2004; Blikra et al., 2006). Since 2005, differential GPS measurements at a total of 19 observation points have been conducted (Hermanns et al., 2011). Even though the mountain slope has rather small movements (NGU, 2018) and shows no sign of increased deformation since 2005, the Norwegian Water Resources and Energy Directorate (NVE), which has the national responsibility for the mapping and prevention of damage caused by large landslides, has recommended that the possibility for large rockslides in the area should be investigated (NVE, 2013). Because both joint water and pressure are important factors for rock-slope stability, it was particularly recommended by NVE to gain more insight into the groundwater flow in the unstable slope. Until 2010, the groundwater hydrology of the unstable slope had not been studied in any detail. Measurements of groundwater recharge into an open fracture thought to represent the back-bounding structure of the northern part of the unstable slope area were initiated in connection with a bachelor thesis at Sogn og Fjordane University College (Brenne et al., 2011). From 2013, the hydrogeological studies continued as a low cost project, in part financed by NVE, with focus on systematic mapping and observations of surface recharge and groundwater discharge in springs in the mountainside and on the fjord bottom (Henriksen \& Dale, 2016). The objective of this study is to integrate the hydrogeological information gathered since 2010 with structural and geomorphic data, and discuss their significance in the light of existing models of rock-slope fracture systems, slope stability and fjord basin hydrodynamics.

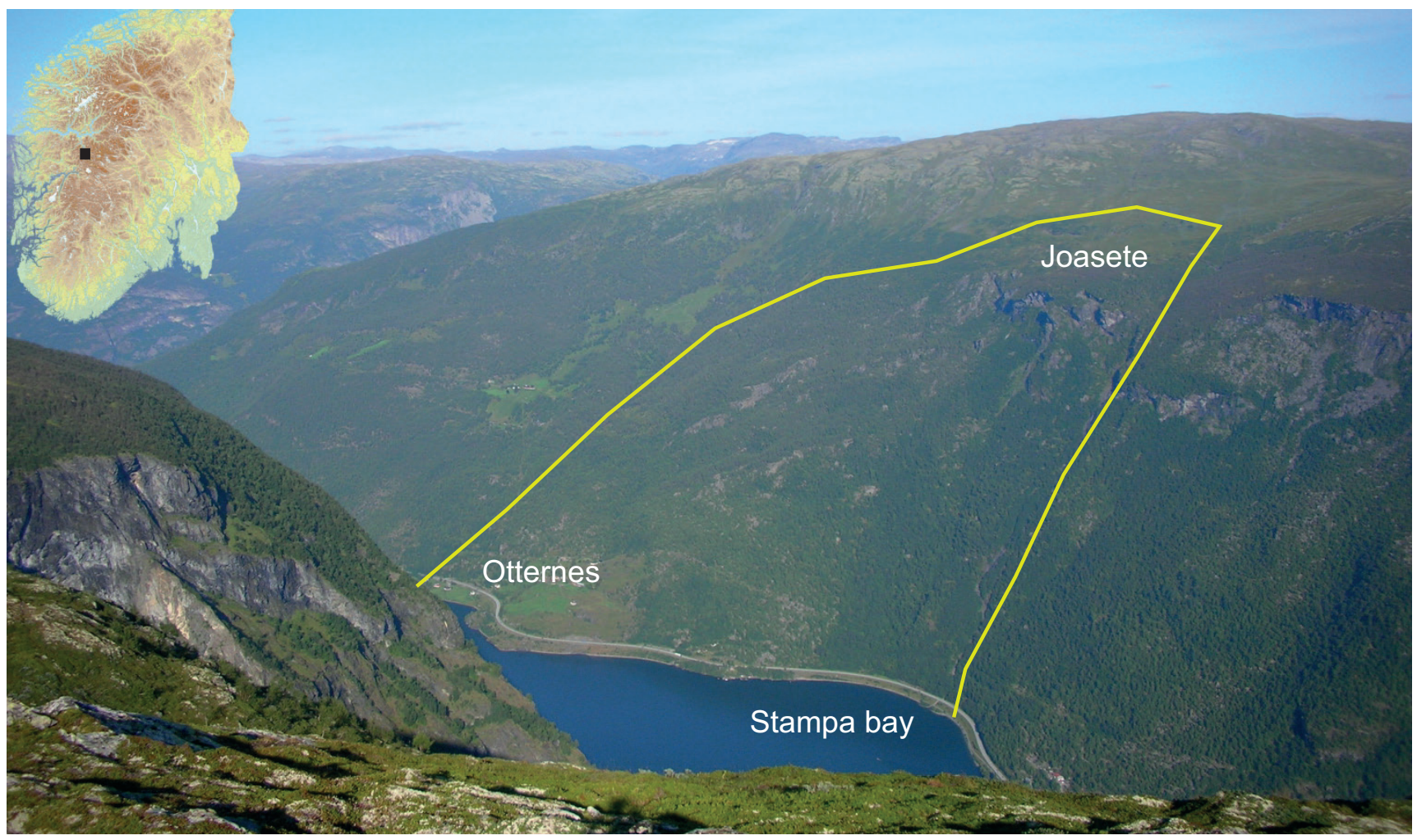

Figure 1. Overview of the unstable rock slope, viewed from the opposing mountainside in the east. The part of the unstable area addressed in this paper is outlined in yellow. The location of the study area in western Norway is indicated by the black rectangle in the inset map. 


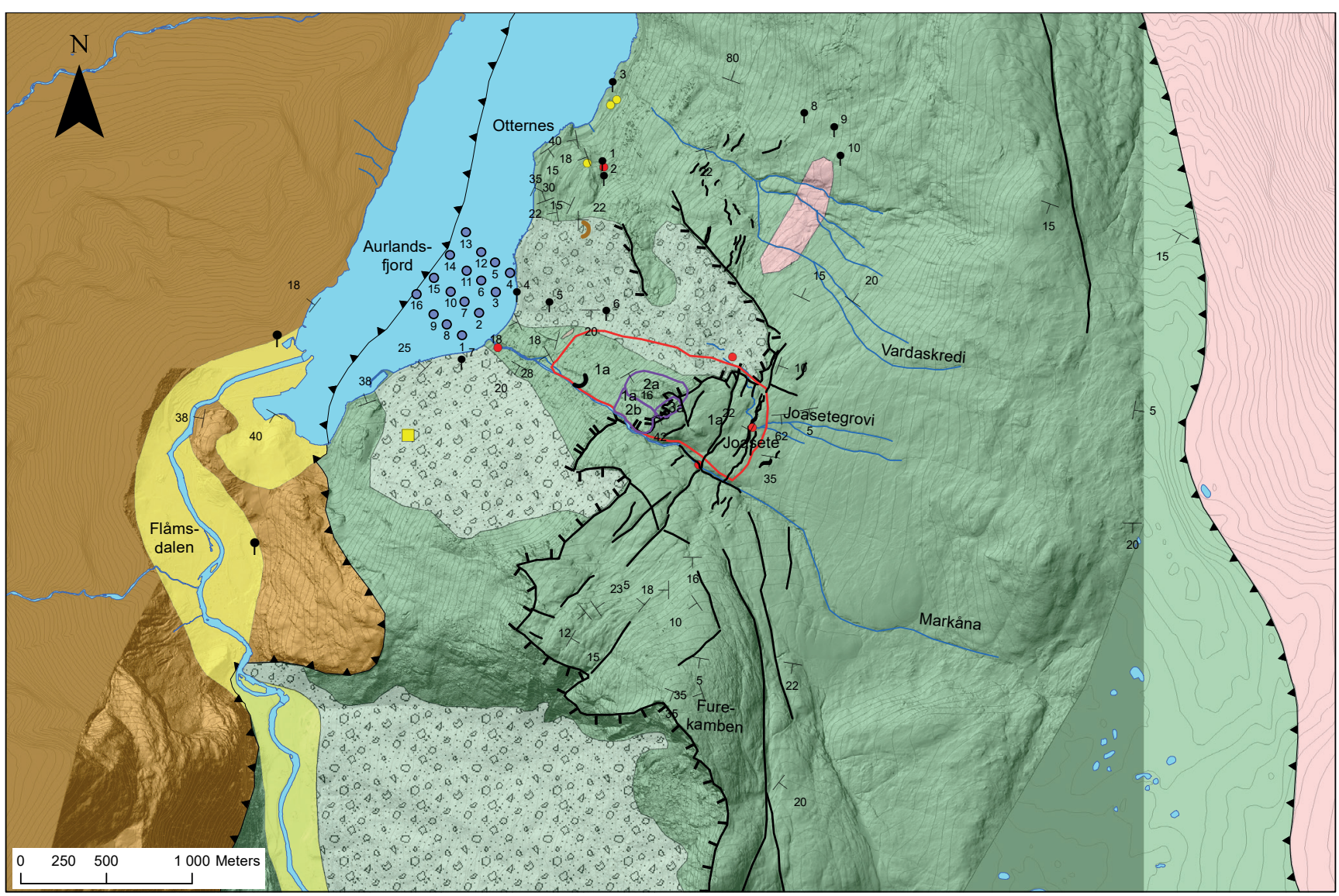

Legend

Bedrock units and geological structures

Middle allochthon
Mangerittic (syenitic) gneiss
Lower allochthon
Phyllite and mica schist
Quartz-schist and blastomylonite
Autochthonous basement
$\square$ Granitic gneiss, migmatite

Holocene deposits and structures

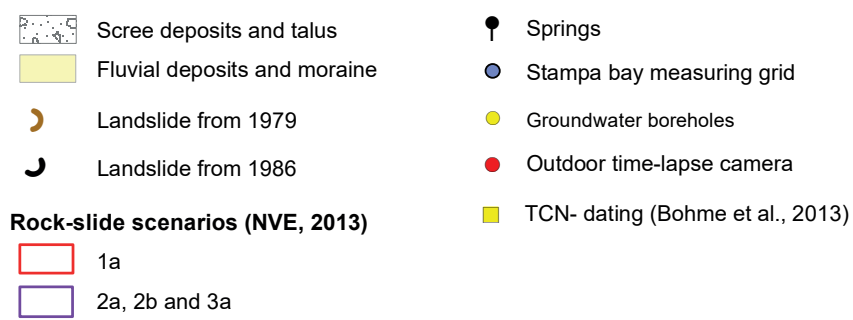

Figure 2. Combined geological and hydrogeological map, overlying a high-resolution DEM that covers the study area. The map shows rock types, main structures, Holocene deposits, springs and observation points. The rockslide scenarios $1 a, 2 a, 2 b$ and 3 (NVE, 2013) are also shown.

\section{Geological and hydrogeological background}

The study area is located in the Caledonian thrust belt of western Norway, and contains thrust sheets of Precambrian basement rocks and Cambrian phyllites. The unstable slope is located in phyllitic rocks and mica schists with two small inliers of mylonitic basement rocks (Fig. 2). It lies sandwiched between two major ductile shear zones, associated with an early phase of Caledonian contractional deformation and a later phase of extensional deformation, which reactivated the contractional shear zones under progressively more brittle conditions. A number of younger semi-brittle faults are also found (Fig. 2). The main planar structure of the phyllitic rocks is the foliation, which has a variable orientation due to several phases of Caledonian folding (Fig. 2) (Böhme et al., 2013).

During the Quaternary era that started at about 2.7 $\mathrm{Ma}$, the area was subjected to several glaciations and deglaciations. It was finally deglaciated in the Early Holocene at about 10,000 to 9,000 years BP (Klakegg et al., 1989; Mangerud et al., 2011; Hughes et al., 2015). The factors that control rock slope stability in this region are probably a combination of the pre-Quaternary bedrock structural geometry, postglacial seismicity, hydrogeology, glacial debutressing and possible vanishing relict permafrost (Blikra et al., 2006; Saintot et al., 2011). Major scarps that represent the release surfaces of former rockslides are clearly visible on photographs and the digital terrain model at $1 \mathrm{~m}$ resolution (Figs. $1 \& 2$ ). In the south, the eastern boundary of the unstable area 
is marked by a $\mathrm{N}-\mathrm{S}$-trending normal fault with a 1-2 metres high scarp (Blikra et al., 2006). Deposits from former rockslides and rockfalls occur as boulder lobes in the slope below the main slide scar in Flåmsdalen and in the Aurlandsfjord. Two of these deposits were dated by cosmogenic nuclide dating (TCN) by Böhme et al. (2013). Boulders from the northernmost boulder lobe gave an average age of 4,300 years $\mathrm{BP}$, that may relate to a single rockslide event. The southernmost lobe gave contrasting ages $(2,400$ and 12,000 years BP) and might represent distinct rockfall events. Seismic profiles and bathymetric data (Domaas et al., 2002; Blikra et al., 2006) indicate that rock-avalanche deposits from the 2,800 years $\mathrm{BP}$ rockslide make up a large part of the fjord bottom. Sea-floor coring (Bøe et al., 2002) shows that a thin blanket of soft sediments overlies the rock avalanche deposits. Echo-soundings and seismic profiling indicate two rockslide deposits in the Aurlandsfjord (Domaas et al., 2002). The larger deposit dates back to the end of the last glaciation (Blikra et al., 2006) and was probably released from the mountain plateau at Furekamben (Fig. 2) at a time when the Flåmsdalen below was still occupied by a glacier. According to Blikra et al. (2006), the rockslide deposits are now found as reworked deposits in Aurlandsfjorden. A smaller rockslide, which has a maximum age of 2,800 years BP (Bøe et al., 2004), is considered to have its source in the slope where the present study has been conducted (Blikra et al., 2006) and could possibly represent the same rockslide as the 4,300 years BP slide dated by Böhme et al. (2013).

The thickness of the rockslide and rockfall deposits in the slope varies between 5 and 50 metres (Geoteam, 1979; Domaas et al., 2002; NVE, 2013), but outcrops of in situ barren rocks also occur within the scree deposits. Creep deformation and sliding within these deposits have occurred, and in 1979 a landslide crossed the road and reached the Aurlandsfjord south of Otternes (Fig. 2). The slip zone was located about $200 \mathrm{~m}$ above the fjord (The Norwegian Road Authority, 1979). In the southern part of the area, large debris flows originating about $400 \mathrm{~m}$ above the fjord took place in 1950 and 1985 (Fig. 2). The trigger mechanism for these slides seems to have been water from snowmelt and precipitation (Sandersen, 1986).

In a simplified stability model, NGI (2008) interpreted the unstable slope as a rockslide area with the foliation of the phyllite acting as a sliding plane and with the open clefts on the plateau formed in response to fjordwards sliding of the rock mass above the sliding planes. Due to the low dip of the sliding planes, water pressure on the sliding planes and the back-cracks was considered necessary to initiate sliding. However, this model is unrealistic because the foliation of the phyllite is too complexly folded to represent a single sliding plane. In addition, resistivity data (NVE, 2013) and field data from this work indicate low water levels in the rock mass on the plateau. Recent structural mapping and the differential GPS measurements carried out in the later years (Braathen et al., 2004; Hermanns et al., 2011; Böhme et al., 2013; NVE, 2013) have resulted in more complex models with scenarios involving movement of discrete and independent blocks by sliding and toppling. In the latest model by NVE (2013), there are eight rockslide scenarios. This work focuses on the northern part of the unstable slope containing scenarios 1a, 2a, $2 \mathrm{~b}, 3 \mathrm{a}$ and $3 \mathrm{~b}$. Scenario 1a, which has a volume of c. 47 million $\mathrm{m}^{3}$, is limited by the back-bounding fracture at Joasete (Fig. 2) and has a sole or toe cropping out at c. $250 \mathrm{~m}$ above the fjord. Scenarios $2 \mathrm{a}$ and $2 \mathrm{~b}$, with volumes of 1.5 and 3.2 million $\mathrm{m}^{3}$, respectively, lie within scenario 1a and are bounded to the east by a major scarp at the edge of the plateau. A potential sliding plane is at c. 550 $\mathrm{m}$ above the fjord. Scenarios $3 \mathrm{a}$ and $3 \mathrm{~b}$ are rock blocks with smaller volumes at the outer edge of the main escarpment. The latest published values in the database for unstable rock slopes accessible at NGU's web page (NGU, 2018) document active movement rates of 1 $\mathrm{cm}$ per year for scenarios $3 \mathrm{a}$ and $3 \mathrm{~b}$. Outside those two independent blocks, the measured movement rates are $0.1-0.4 \mathrm{~cm}$ per year. The movement rates of scenario $3 \mathrm{a}$ (Joasetebergi) are permanently monitored (NGU, 2018).

The mountain slope bounded by the rivers Markåna in the south and Vardaskredi in the north is considered a local groundwater flow system, and is the main subject of the present study. Springs are discharging groundwater at various levels in the slope and, as discussed later in this paper, probably also from the fjord bottom. Visual observations and water discharge measurements demonstrate that surface water in the small rivers that drain the higher lying areas east of Joasete partly or wholly infiltrates the major open fracture zone in the release zone for a potential rockslide near Joasete (ECO, 2009; Brenne et al., 2011). Exploration drillings, carried out with a hand-held motor breaker and georadar profiles, indicate that the open fracture on the plateau contains phyllitic blocks down to at least $17 \mathrm{~m}$ depth (Brenne et al., 2011). Slug tests carried out in a piezometer installed at 10 metres depth failed because it was not possible to obtain a stable water level in the piezometer. A water level datalogger installed at 8 $m$ depth showed no signs of having been under water during a half-year measuring period. This shows that the open fracture can transmit significant volumes of water without affecting the hydraulic head. Hence, the open fracture zone is a highly permeable sink for which recharge can be further routed to the fracture system in the mountain slope.

\section{Methods}

\section{Structural and geomorphic data}

Structural data were collected in the field during the period 2008-2010 in connection with a common project 
between NGU, Sogn og Fjordane County, NVE, University of Oslo and Sogn og Fjordane University College (Hermanns et al., 2011) and as part of the hydrogeological mapping in the period 2013-2017. The structural data comprise measurements of joints and foliation surfaces at about 120 and 90 localities, respectively. The orientation of geomorphic data (Fig. 2) such as open fractures and lineaments were determined from a digital elevation model based on airborne laser scanning data with 1 $\mathrm{m}$ resolution. New bathymetric data at $1 \mathrm{~m}$ resolution based on multibeam echo soundings carried out by the Norwegian Hydrographic Service became available in 2016. They provide additional information of the seabed geomorphology in the study area.

\section{Groundwater recharge to bedrock}

The catchment of Joasetegrovi, which lies in the hillslope above the main back-bounding structure (Fig. $3 \mathrm{~A}$ ), is the principal contributor to the observed and indicated groundwater runoff in the form of springs and seeps in the mountain slope above the fjord and on the fjord bottom. However, the lack of site-specific hydrogeological data from observation boreholes precludes an exact delineation of the area contributing to recharge and precise quantification of recharge to the bedrock aquifer of the rockslide area.

The recharge of the catchment precipitation to the bedrock takes place by (1) in situ percolation of the precipitation and by (2) infiltration of the surface runoff through the open back-bounding fracture in the pasture area at Joasete. The essentially barren bedrock in the catchment above the plateau with the back-bounding fracture has a normal fracture frequency with few or no open fractures. The in situ recharge (1) is estimated by applying recharge rates for fractured rocks from the literature, which may be $20 \%$ or less of the annual precipitation (Singhal \& Gupta, 1999, p. 257; Knutsson \& Morfeldt, 2002, p. 32), but could be as low as $1 \%$ (Thorne \& Gascoyne, 1993).

The surface runoff in the catchment is routed by smaller creeks towards Joasetegrovi before it crosses the open back-bounding fracture by the pasture area. The infiltration of the surface runoff (2) has been calculated by means of water discharge measurements in Joasetegrovi upstream and downstream of the open fracture (Fig. 3B, C) (Brenne et al., 2011) applying the salt dilution method (Merz \& Doppmann, 2006). In total, six measurements were made on days with variable discharge. Water levels (gauge heights) at the measuring stations were logged daily three times per day with a Van Essen TD-diver, and water discharge curves for the autumn 2010 and spring 2011 were established based on the discharge measurements and gauge heights. This made it possible to find the daily discharge in the river upstream and downstream of the recharge area. The daily recharge to the open fracture was calculated as the difference between the upstream and the downstream river discharge. In addition, semi-

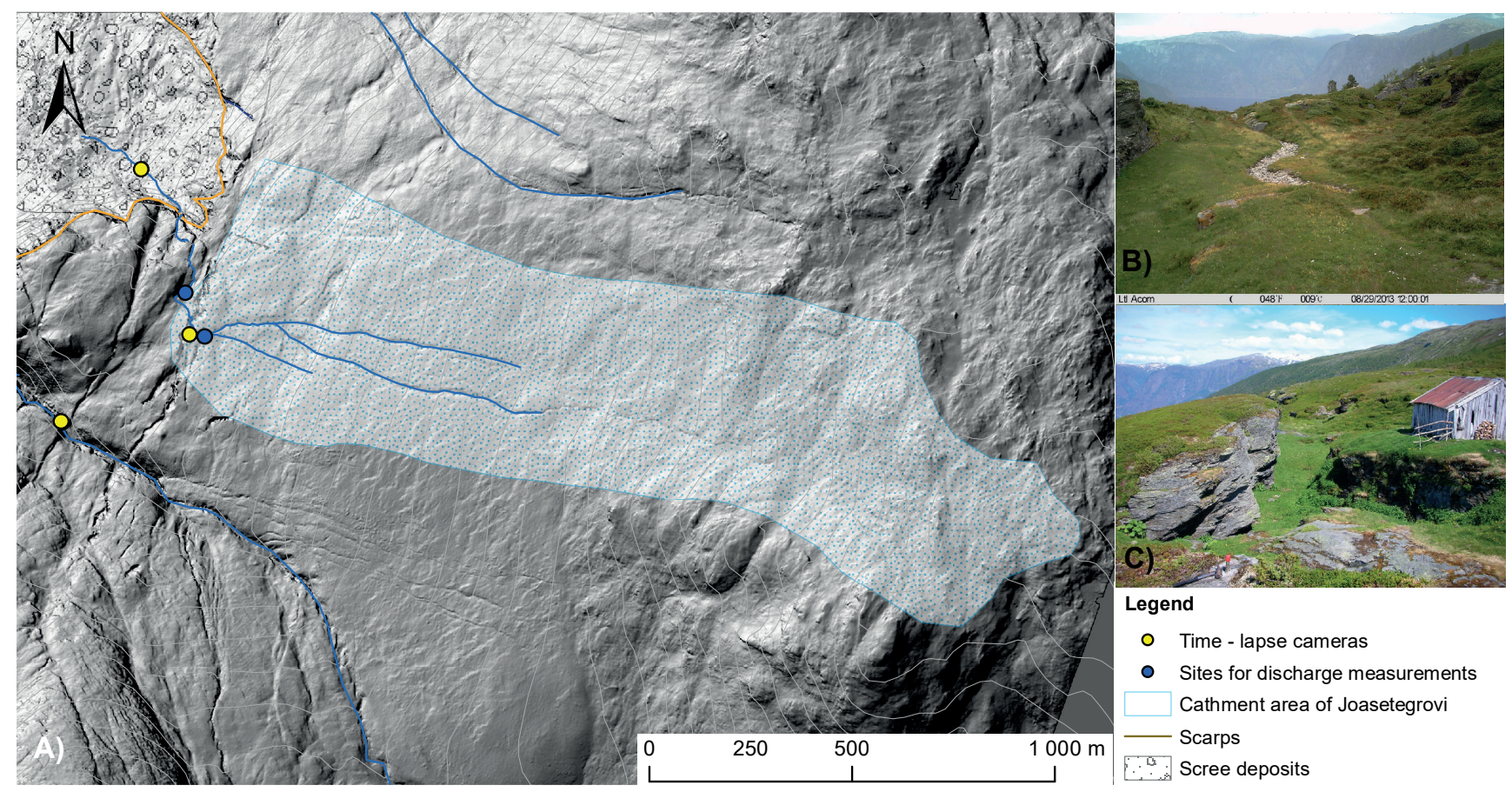

Figure 3. (A) Map of the catchment area for Joasetegrovi showing sites for discharge measurements and time-lapse cameras. The catchment area was delineated from a digital topographic map with $1 \mathrm{~m}$ contour lines. (B) The recharge area where Joasetegrovi flows across the backbounding fracture is located between the two sites for discharge measurements marked in Fig. 3A. (C) The back-bounding fracture at Joasete. 
quantitative measurements of recharge were made by means of outdoor timelapse cameras installed at the sites and focused on the river gauge used to measure water levels during the periods September-October 2013 and from the end of July 2014 to August 2015 (Henriksen \& Dale, 2016).

\section{Groundwater discharge from onland springs}

Groundwater discharge areas were identified by field mapping of springs and seeps in the slope towards the Aurlandsfjord. To exclude temporary springs, the mapping was carried out in late winter/early spring. Altogether, 10 springs were located (Fig. 2). Two of the springs discharge from rock fractures, while the others have their discharge through scree-deposits. Because the springs are in use for domestic water supplies, it was not possible to carry out exact discharge measurements, as this would require removal of the protective structure at the collection point. Hence, semi-quantitative estimates of discharge are based on measurements of overflow (i.e., Fig. 4A, C), with an addition of the supposed water withdrawal at the supply points based on information given by the owners. In addition, electrical conductivity and temperature were measured with a temperatureconductivity pocket meter WTW cond 340i. Since November 2016, electrical conductivity, temperature and hydraulic heads are being measured in two private drilled boreholes near Otternes (Fig. 2).

\section{Fjord basin dynamics and submarine groundwater discharge}

Fjords have normally three main layers (Farmer \& Freeland, 1983). At the top is a layer of freshwater/ brackish water, which is strongly influenced by the supply of freshwater. Below this is an intermediate layer which goes down to the threshold-depth for saline fjord water. Since there is no threshold in the Aurlandsfjord, it means

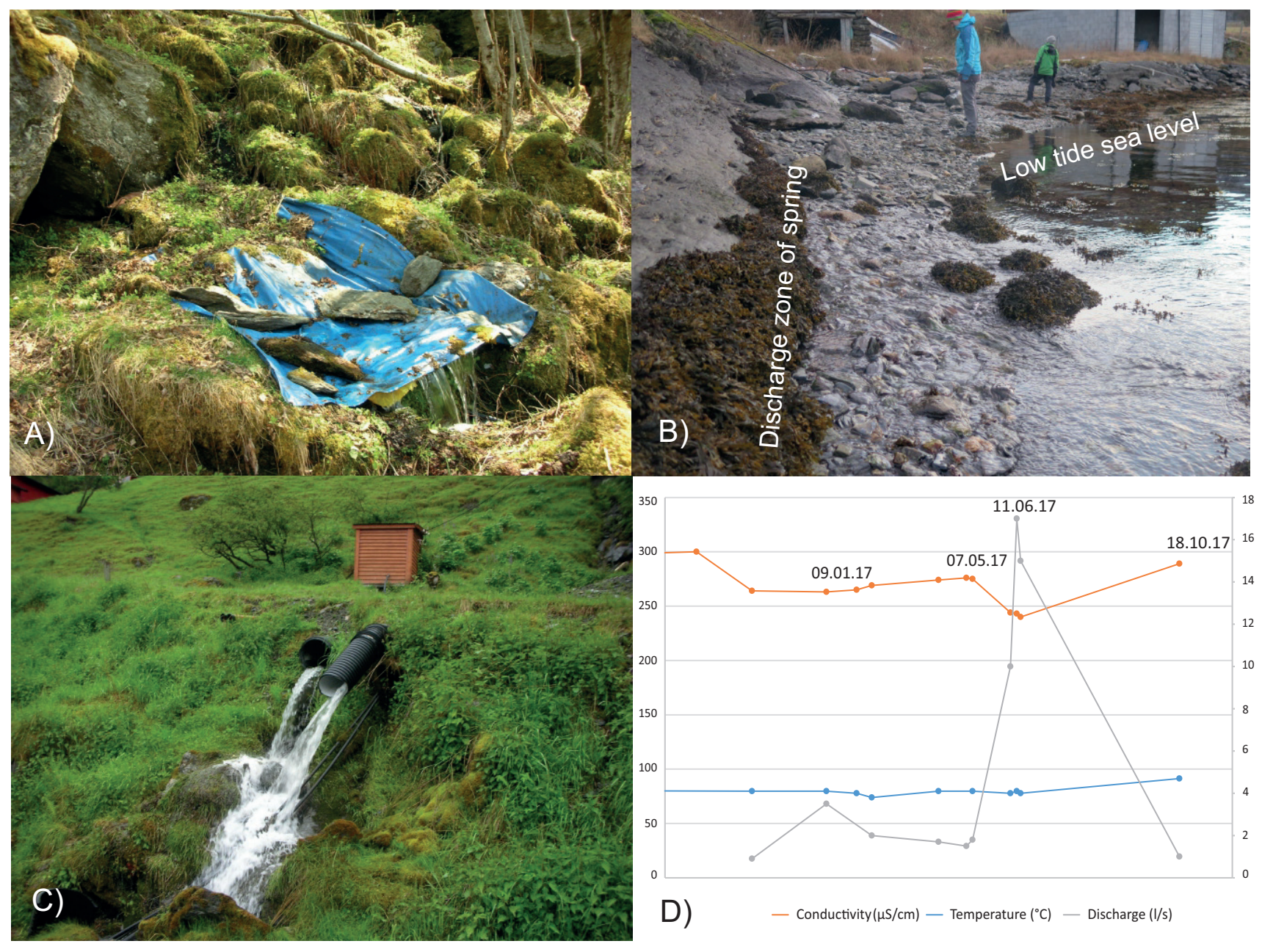

Figure 4. (A) Spring 5 (Vassteinane) discharges from scree deposits. The overflow is about two litre/second. (B) Spring 3 (Bøen) discharges through foliation-parallel joints. This spring discharges beneath sea level at high and intermediate tides and above sea level at low tides. (C) Overflow from spring 1 at Otternes. The spring is located by the small red building. (D) Plot of discharge $(l / s)$, temperature $\left({ }^{\circ} \mathrm{C}\right)$ and electrical conductivity $(\mu \mathrm{S} / \mathrm{cm})$ in spring 1 for a one-year period. The high discharge in early June coincides with a small decrease in electrical conductivity while temperature is unchanged. 
that the intermediate layer extends down to c. $165 \mathrm{~m}$, which is the threshold-depth in the Sognefjord. Beneath the intermediate layer is the fjord basin water. The ford depth in the investigated part of the Aurlandsfjord is c. $50 \mathrm{~m}$. Hence, our hydrographic measurements were conducted in the freshwater/brackish water layer and in the intermediate layer. Within fjords, the intermediate layer may consist of several homogeneous layers separated by inhomogeneous layers (T. Dale, pers.comm., 2017). Most probably, this relates to local effects of larger river discharges at different places in the fjord. Under stable conditions with no current, rising freshwater from the fjord bottom will mix with the fjord water of the intermediate layer and storesat a depth depending on the density of the mixed water (McClimans et al., 2002). In winter, when there is little river discharge of freshwater and hence less difference in salinity between the upper and deeper layers, rising freshwater can store in the freshwater/brackish layer.

Submarine groundwater discharge (SGD) is a common phenomenon in coastal zones and can be assessed by a variety of methods (Burnett et al., 2006; Saito et al., 2011). The identification of areas with SGD in this work relies on the interpretation of high-resolution measurements from vertical profiling of seawater density, salinity and temperature in the different water layers. A water layer is characterised by density, which depends on salinity and temperature. In a homogeneous layer, there is little variation in density and salinity with depth. An inhomogeneous layer has large changes over short depth intervals and often forms transition-layers between the homogeneous layers.

In order to identify possible areas of submarine groundwater discharge, a rectangular grid with 16 observation points was established in the Stampa bay (Fig. 2). The location of the grid was chosen from where we found it most likely that groundwater could discharge, and also with information given by local inhabitants who had formerly observed the emergence of bubbles and other signs compatible with upwelling of freshwater in this area. At each observation point, the physical parameters of the water column were measured every second with a submersible profiler of the type STD-SAIV 204. The measurements extended down to $35 \mathrm{~m}$ depth. The instrument measures the following parameters: water depth $(\mathrm{m})$, salinity (psu), temperature $\left({ }^{\circ} \mathrm{C}\right)$, density (sigma-t), oxygen $(\mathrm{mg} / \mathrm{l})$, chlorophyll $(\mu \mathrm{g} / \mathrm{l})$ and turbidity (FTU). Density is given in sigma-t units. This is calculated as the in situ measured density $\rho$ of seawater $\left(\mathrm{kg} / \mathrm{m}^{3}\right)$, which depends on salinity $(\mathrm{S})$ and temperature $(\mathrm{t})$, minus $1\left(\mathrm{~kg} / \mathrm{m}^{3}\right)$, multiplied by 1000 :

Sigma- $t=[\rho(S, t)-1] \times 1000$

Pressure has been reduced to atmospheric, i.e., water pressure $p=0$. For standard seawater with density 1.027 $\mathrm{kg} / \mathrm{m}^{3}$, sigma- $\mathrm{t}=27$.
Measurements were also taken at three reference stations $3-4.5 \mathrm{~km}$ farther out in the Aurlandsfjord.

The farthest station is located near a submersed discharge point of freshwater form the Vangen Hydroelectric Power plant in Aurland.

\section{Results}

\section{Structural and geomorphic data}

On the plateau by the mountain pasture at Joasete, the phyllitic bedrock is dissected by NNE-SSW, $\mathrm{N}-\mathrm{S}$ and ESE-WNW vertical and near-vertical fractures (Figs. 2 \& 5A). The NNE-SSW fractures typically form trench-like structures (cf., Agliardi et al. 2001). The most prominent of these structures is the back-bounding fracture that runs through the Joasete area. It is between 5 and 30 metres wide and is persistent for about $4 \mathrm{~km}$ along strike. It appears to have opened along pre-existing NNE-SSW and WNW-ESE joints (Fig. 5C). In some places, erratic boulders of basement rocks are found in the open fracture. Contrary to the area in the south, there is no clear normal fault that forms the eastern boundary of the unstable area at Joasete. The mean foliation plane dips at about $11^{\circ}$ towards the fjord (Fig. $5 \mathrm{~A}$ ), but locally it may dip at shallow angles either into the mountain slope or towards the fjord. Where the foliation is steeper, probably in the hinge zones of folds, it has more variable dip directions.

Small-scale, northwest-facing shear folds of the foliation are commonly observed at the outcrop scale. Due to the lack of good marker horizons and the limited amount of structural data, a large-scale fold pattern has not been mapped out for the study area. At the outcrop scale in the field, a stepwise fracture pattern formed by a combination of steeply dipping fractures and a flat foliation or low-angle shear fractures is quite commonly observed in the phyllites (Fig. 5B).

\section{Groundwater recharge to bedrock}

In situ recharge to bedrock

The catchment area for the open fracture (Fig. 3) has an area of c. $0.8 \mathrm{~km}^{2}$. The average yearly precipitation is c. $1,800 \mathrm{~mm} /$ year (NVE, 2002). In the simple short-cut calculations (Table 1) the estimates of in situ recharge to the bedrock based on values from the literature are found to vary from 18 to $360 \mathrm{~mm} /$ year, corresponding to about $0.5-9.1 \mathrm{l} / \mathrm{s}$.

\section{Recharge to the open fracture at Joasete}

The evapotranspiration in the catchment is c. $400 \mathrm{~mm} /$ year (NVE, 2002). Hence, net precipitation is c. 1,400 $\mathrm{mm}$ /year. By subtracting the recharge estimates from the 

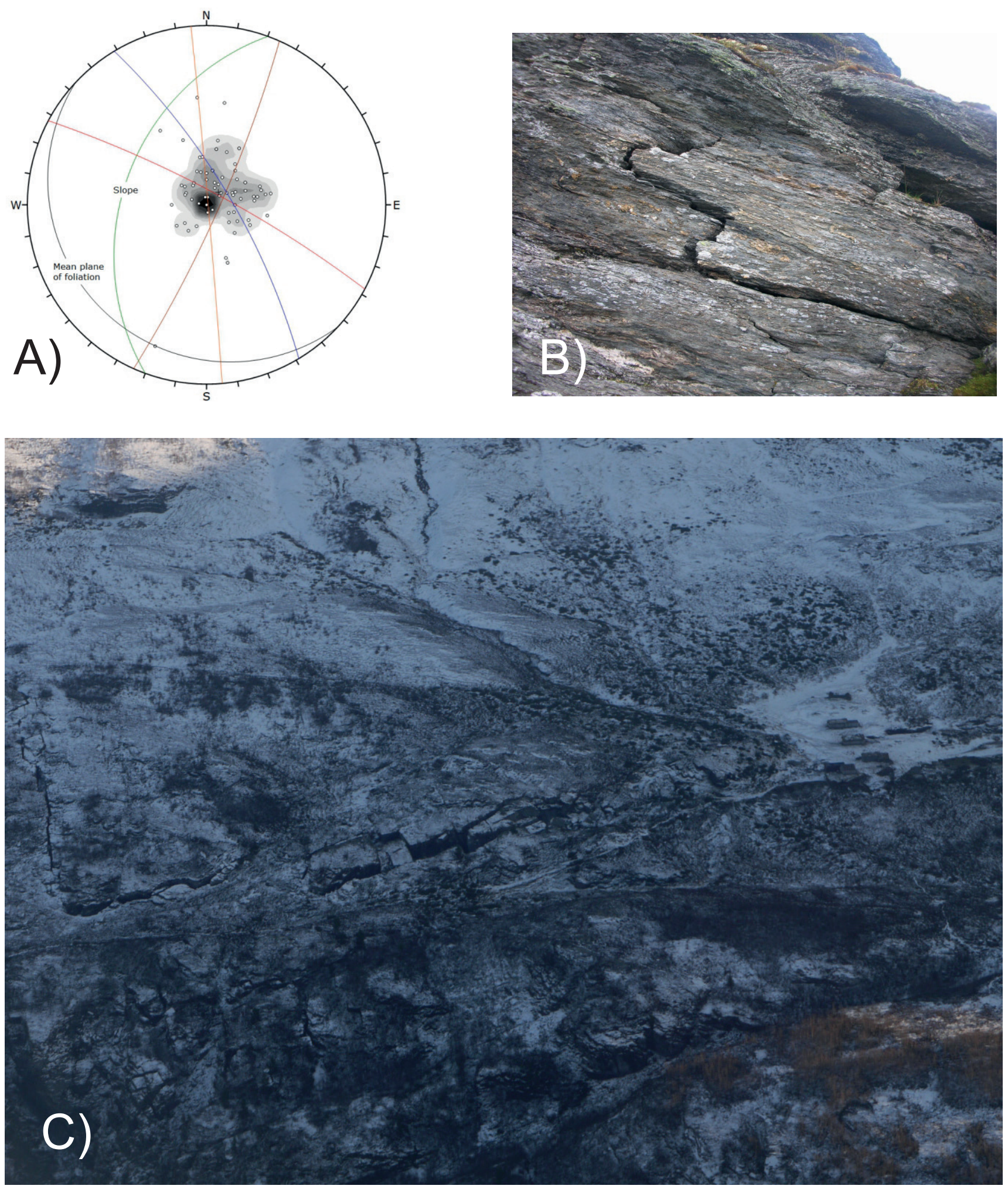

Figure 5. (A) Stereographic plot of poles to foliation in the phyllites/mica schists. Also shown are stereographic projections of the mean plane to the foliation in the phyllites/mica schists, the slope beneath the plateau and the mean planes of fracture sets. (B) Typical step-fractures developed in mica schists. The orientation changes from foliation-parallel to foliation-perpendicular. A fracture pattern like this might be the result of a change in orientation of the fracture in relation to the local stress field during its growth, or a structure, i.e., foliation, that the fracture tip meets during its propagation. (C) Aerial view of the back-bounding fracture northeast of Joasete showing how it opens along pre-existing NNE-SSW and ESE-WNW joints 
Table 1. Summary table with values used to calculate recharge to bedrock and recharge to the back-bounding fracture for the catchment area of Joastegrovi.

\begin{tabular}{lcccc}
\hline & $\begin{array}{c}\text { Recharge } \\
(\mathrm{mm} / \text { year })\end{array}$ & $\begin{array}{c}\text { Infiltration to } \\
\text { bedrock }(\mathrm{l} / \mathrm{s})\end{array}$ & $\begin{array}{c}\text { Net precipitation } \\
(\mathrm{mm} / \text { year })\end{array}$ & $\begin{array}{c}\text { Runoff } \\
(\mathrm{mm} / \text { year })\end{array}$ \\
\hline $\begin{array}{l}\text { Recharge } \\
\text { (\% of average } \\
\text { precipitation) }\end{array}$ & & & & \\
\hline $1 \%$ & 18 & 0.5 & 1400 & 1382 \\
$10 \%$ & 180 & 4.6 & 1400 & 1220 \\
$20 \%$ & 360 & 9.1 & 1400 & 31 \\
\hline
\end{tabular}

net precipitation the average surface runoff is found to be in the order $1040-1382 \mathrm{~mm} /$ year per $\mathrm{km}^{2}$ or between 26 and $35 \mathrm{l} / \mathrm{s}$ for the catchment (Table 1). It is considered that this water is routed along smaller creeks and the bedrock/soil interface towards Joasetegrovi (Fig. 3). Table 1 summarises the groundwater and surface runoff based on these assumptions.

The discharge in Joasetegrovi is strongly dependent on precipitation and it has no/minimum discharge during dry periods and in winter. The measured discharge of Joasetegrovi by the salt dilution method upstream and downstream of the open fracture varies between $5 \mathrm{l} / \mathrm{s}$ and $105 \mathrm{l} / \mathrm{s}$ and between $0 \mathrm{l} / \mathrm{s}$ and $87 \mathrm{l} / \mathrm{s}$, respectively (Brenne et al., 2011). However, the high maximum discharge values of $105 \mathrm{l} / \mathrm{s}$ and $87 \mathrm{l} / \mathrm{s}$ followed snowmelt and storm precipitation. Excluding the extreme value, a maximum discharge of Joastegrovi before it flows across the open fracture is $32.6 \mathrm{l} / \mathrm{s}$. Altogether, given the uncertainties in the runoff values, there seems to be a good correspondence between the estimated average discharge in Table 1 and the actually measured discharge by the salt dilution method. The river discharge in Joastegrovi at the outlet of the catchment, before it flows across the back-bounding fracture, represents the water available for fracture-infiltration. Fig. 6 shows a plot of the upstream discharge against the difference between the upstream and the downstream discharge, i.e., the amount of water that infiltrates into the fracture zone. When the discharge in Joasetegrovi is small, all the water infiltrates into the fracture zone; otherwise, about $20 \%$ of the river discharge infiltrates. This gives a maximum recharge of $c$. 17 l/s during high water flows. The excess water that does not recharge to the fracture zone follows the downstream course of Joasetegrovi and finally flows out across the main escarpment into talus deposits at the base. From there it follows a defined river course farther downslope. Time-lapse camera monitoring shows that this river course is only active during snowmelt and extreme precipitation events; otherwise, there is a dry creek.

\section{Groundwater discharge}

Groundwater discharge from onland springs

Groundwater is discharging from a number of springs in the mountain slope above the fjord (Fig. 2). The electrical conductivity in the springs in the mountain slope varies, but is about 3-12 times higher than that of the recharging surface water on the plateau by Joasete (Table 2). One population (1) of springs consists of the springs $8-10$

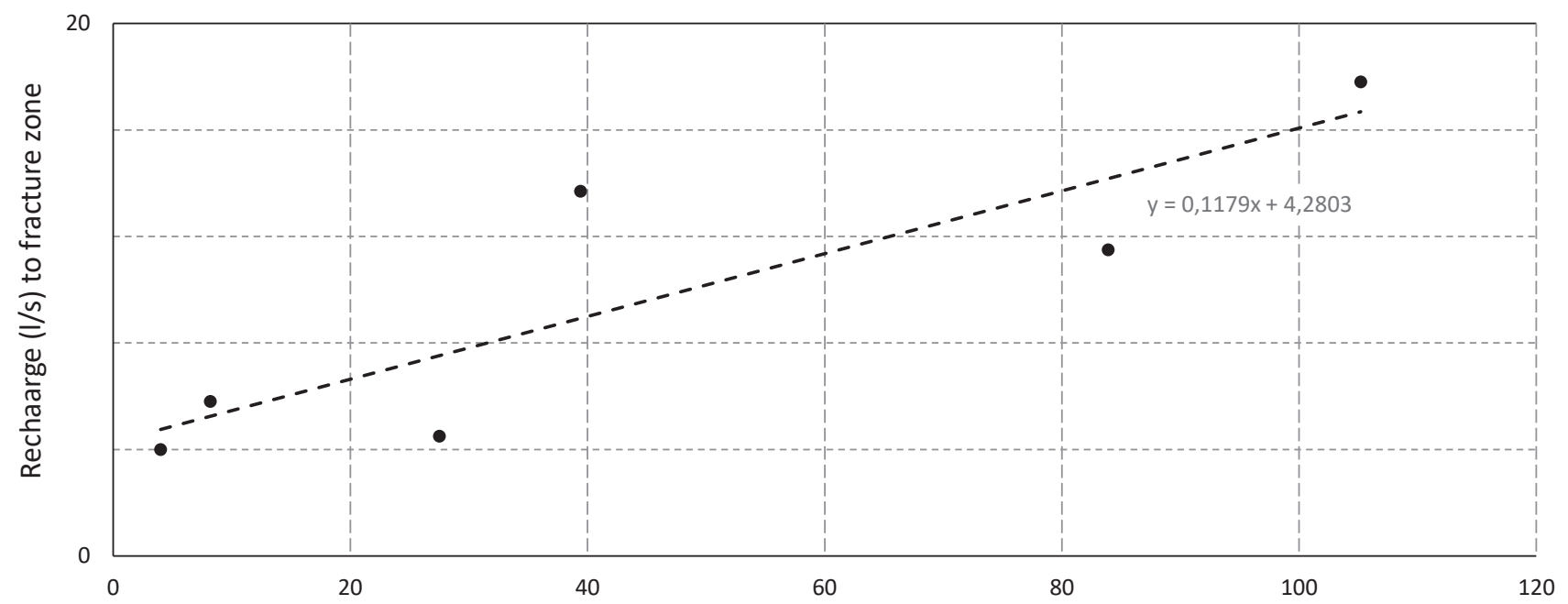

Figure 6. Total discharge in Joasetegrovi upstream of the open fracture at Joasete plotted against the recharge in the fracture zone. The point data are based on discharge measurements with the salt dilution method. 
Table 2. Measurements of electrical conductivity $(\mu \mathrm{S} / \mathrm{cm})$, temperature $\left({ }^{\circ} \mathrm{C}\right)$ and discharge for springs 1-6 (population 2), spring 7 and springs 8-10 (population 1) compared with the surface water in Joasetegrovi and Markann. There is a significant difference in hydrochemistry between the surface water and spring water, and between the spring water of population 1 and population 2 springs. The sampling points are shown in Fig. 2.

\begin{tabular}{|c|c|c|c|c|c|c|c|c|c|c|c|c|}
\hline & \multicolumn{10}{|c|}{ Onland springs } & \multicolumn{2}{|c|}{ Surface water } \\
\hline & 1 & 2 & 3 & 4 & 5 & 6 & 7 & 8 & 9 & 10 & Joasetegrovi & Markåna \\
\hline Discharge $(l / s)$ & $n=8$ & & $n=2$ & & $n=3$ & $n=2$ & & & & & & \\
\hline Range & $1.9-4$ & nd & $1-2.5$ & & $2-3.5$ & $1-2$ & & & & & & \\
\hline Median & 2.1 & nd & 1.75 & & 2.5 & 1.5 & & & & & & \\
\hline Mean & 2.45 & nd & 1.75 & & 2.7 & 1.5 & & & & & & \\
\hline Temperature $\left({ }^{\circ} \mathrm{C}\right)$ & $n=15$ & $n=4$ & & & $n=9$ & $n=1$ & & $n=2$ & $n=2$ & $n=2$ & $n=2$ & $n=2$ \\
\hline Range & $3.5-4.7$ & $3.4-4.2$ & & & $4.2-7.5$ & & & $4.6-4.8$ & $1.3-3.8$ & $2.2-3.5$ & $1.7-1.9$ & $3.7-9.5$ \\
\hline Median & 4.1 & 4 & & & 5.8 & 3.8 & & 4.7 & 2.6 & 2.8 & & \\
\hline Mean & 4.0 & 3.9 & & & 5.7 & 3.8 & & 4.7 & 2.5 & 2.8 & 1.8 & 6.6 \\
\hline $\begin{array}{l}\text { Electrical conductivity } \\
(\mu \mathrm{S} / \mathrm{cm})\end{array}$ & $n=25$ & $n=4$ & & & $n=12$ & $n=1$ & $n=1$ & $n=2$ & $n=2$ & $n=2$ & $n=4$ & $n=3$ \\
\hline Range & $200-300$ & $264-285$ & & & $177-268$ & & & $50-55$ & $62-64$ & $60-62$ & $21-24$ & $16.3-22.2$ \\
\hline Median & 261 & 271 & & & 243 & 208 & 214 & 52.5 & 63 & 61 & 21.8 & 22 \\
\hline Mean & 255 & 272 & & & 231 & 208 & 214 & 52.5 & 63 & 61 & 22.1 & 20.1 \\
\hline
\end{tabular}

and has electrical conductivities in the range between 50 and $60 \mu \mathrm{S} / \mathrm{cm}$ and variable temperature. Population 1 represents shallow groundwater with short residence times and with flow paths in the unconsolidated overburden. Moreover, we consider these springs to belong to a separate flow system with recharge- and discharge-zones north of the study area. Spring seven lies west of the river Markåni and is considered to belong to a separate flow system. Springs 7-10 are temporary springs and were not studied in any detail.

Population 2 consists of the springs 1-6. They have conductivity values in the range $200-300 \mu \mathrm{S} / \mathrm{cm}$ and show little variation in temperature. Spring discharge, electrical conductivity and temperature are summarised in Table 2. Because of their location in the intertidal zone, there are few or no measurements for springs 3-4, but the discharge from spring three is estimated to vary between 1 and $2.5 \mathrm{l} / \mathrm{s}$. Spring four has the character of a seepage zone and the discharge is visible only at low tide and when the sea surface is very calm. The total discharge from the springs of this population in the mountain slope above the fjord varies between 5.9 and $12.5 \mathrm{l} / \mathrm{s}$, depending on season.

Data for spring 1 for the period 2016-2017 are plotted in Fig. 4D and show a peak discharge of c. 10-17 1/s in a two-week period in May-June 2017. Electrical conductivity is slightly reduced during this period, but temperature is unaltered. According to local people, this period with abnormal discharge from spring 1 occurs yearly at about this time. A similar pattern may also be observed for spring 5 .

\section{Submarine groundwater discharge}

The profile measurements were carried out as four measuring series: 25 October 2013, 26 November 2013, 7 March 2014 and 17 August 2014. The resolution of the measurements makes it possible to record water layers with a minimum thickness of $22-38 \mathrm{~cm}$. Within homogeneous layers, thin microlayers displaying, for example, small but significant changes in salinity, can be identified. Each of our four measurement series illustrates the depth variation for the measured physical parameters in the 16 measuring points and 3 reference stations. All the measured parameters were analysed, but salinity and density yielded the clearest contrast between the measuring stations. Hence, only these parameters are discussed in this paper. Temperature was also considered, as it shows differences between the stations in the grid and the reference stations. After each measuring series, the data from each station were imported into a spreadsheet and plotted as depth-parameter plots. Deviations from the general pattern for one measuring point, for example lower salinity, could be a signal of rising groundwater from the fjord bottom beneath that measuring point.

\section{Measurements 25 October 2013}

There were no reference stations in this measurement series. All the stations 1-16 show the same general pattern with two layers for salinity and density. From 0-10 $\mathrm{m}$ depth there is an upper inhomogeneous layer followed by a homogeneous layer from 10 to $35 \mathrm{~m}$ (Fig. 7). This layer extends probably to greater depths, but we have only measurements down to $35 \mathrm{~m}$. The temperature 

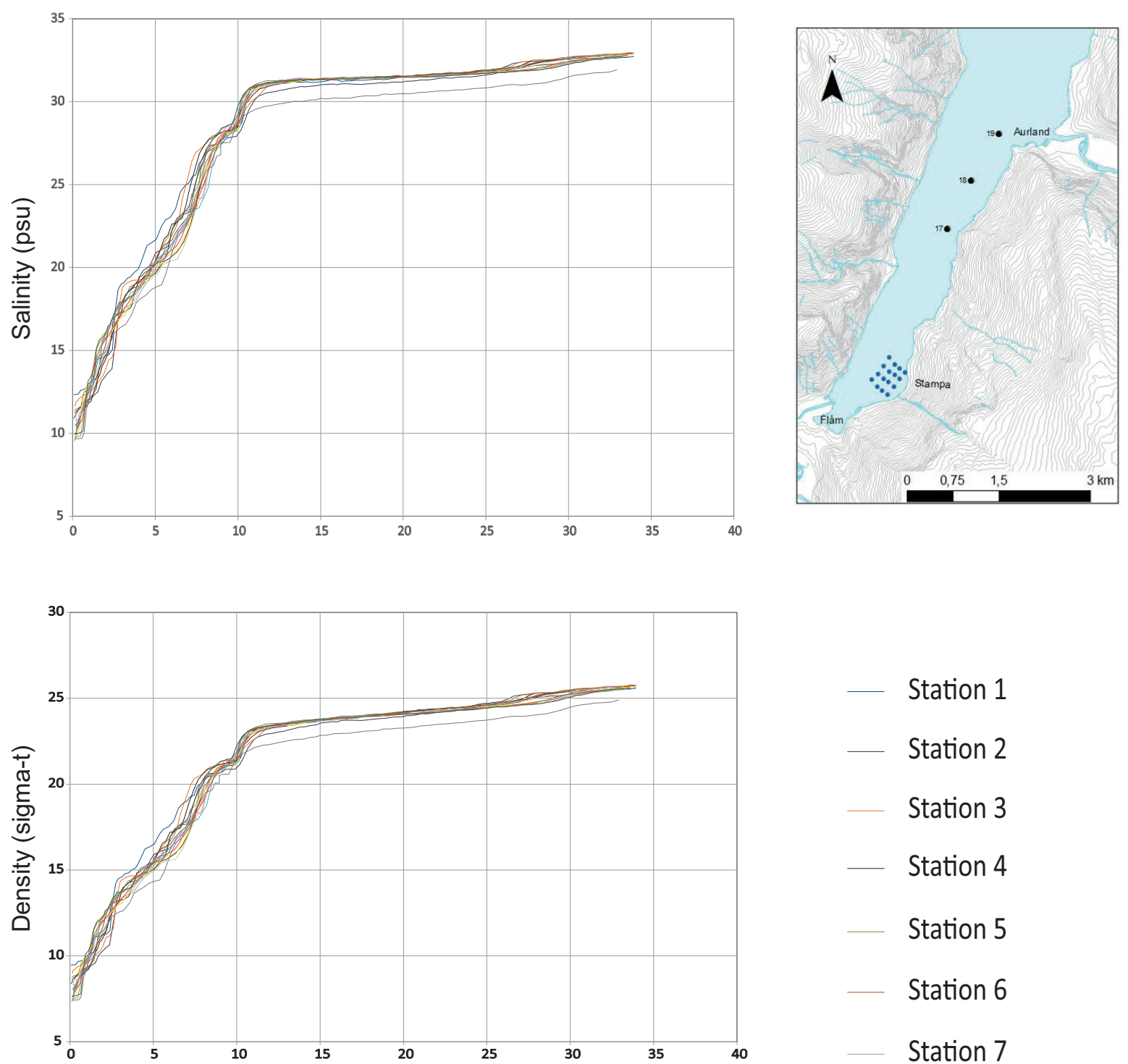

Station 1

Station 2

Station 3

- Station 4

Station 5

Station 6

Station 7

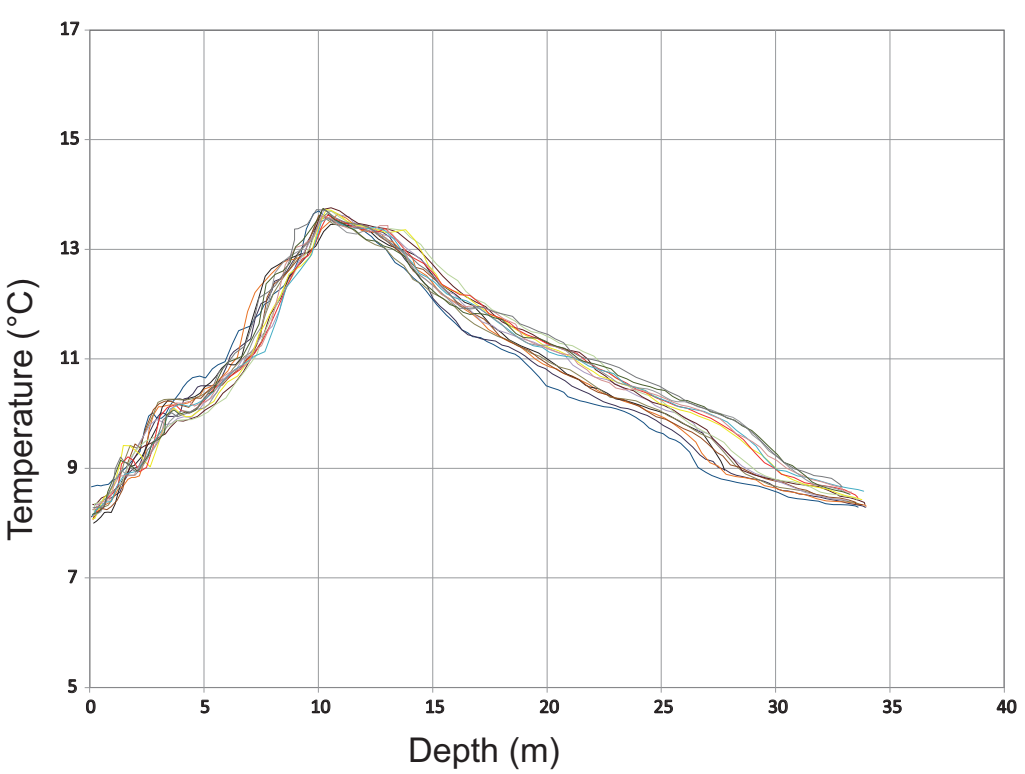

Station 8

Station 9

Station 10

Station 11

Station 12

Station 13

Station 14

Station 15

Station 16

Figure 7. Salinity, density and temperature measurements recorded by stations in the fjord for measuring series 1, 25 October 2013. All stations show the same pattern with two salinity-and density-layers. There were no reference stations for this series. 
profiles show the same layering. In the inhomogeneous upper layer, the temperature is gradually rising from $\mathrm{c}$. $8^{\circ} \mathrm{C}$ to $\mathrm{c} .13 .5^{\circ} \mathrm{C}$, and gradually decreasing to c. $8.5^{\circ} \mathrm{C}$ in the lower homogeneous layer. Station 16 is different from the other stations by having a lower salinity (1-2 psu) and density (c. 1 sigma-t) in the homogeneous layer.

\section{Measurements 26 November 2013}

This measuring series shows two inhomogeneous and two homogeneous layers (Fig. 8). The stations have a thin, inhomogeneous layer down to c. $2 \mathrm{~m}$ depth. The first homogeneous layer extends to c. $8 \mathrm{~m}$. Here, salinity increases from c. $23-24$ to c. 26 psu, and density from c. 19 to 20 sigma-t. The second inhomogeneous layer is found between c. 8 to $14 \mathrm{~m}$ depth. In this layer, salinity increases from c. 26 to 31 psu, and density from c. 20 to 24 sigma-t. Stations 4, 6 and 11 differ from the general pattern by having 1-2 psu lower salinity values and lower density values. The temperature profiles show the same four water layers as the salinity- and density-profiles. Reference station 17 follows the same pattern described for the other stations and shows no deviation like that shown for stations 4,6 and 11 . The temperature, however, is in general somewhat lower from c. 4-8 m depth and somewhat higher below $15 \mathrm{~m}$ depth. We have no good explanation for these differences.

\section{Measurements 7 March 2014}

This measuring series also has four layers for all stations (Fig.9). Stations 4, 9 and 11 have clearly lower values for salinity and density in all layers. The difference is largest in the upper homogeneous layer, where salinity is 2-4 psu lower. Stations 4 and 9 have almost identical values, while station 11 has the lowest values. The temperature profiles are quite similar for all stations and lie between 6 and $6.5^{\circ} \mathrm{C}$ with only small variations with depth. Reference station 17 has the same pattern for density and salinity as the main grouping of stations. As regards temperature, it differs by having a lower temperature from 7 to $35 \mathrm{~m}$ depth, especially in the interval $12-35 \mathrm{~m}$.

\section{Measurements 17 August 2014}

This series also has two inhomogeneous and two homogeneous layers for all stations (Fig. 10). The first inhomogeneous layer extends to c. $2 \mathrm{~m}$ depth. Salinity increases from c. 6-7 psu to $12-13$ psu; while density increases from c. 4-5 sigma-t to c. 8-9 sigma-t. The first homogeneous layer is from 2 to $6-7 \mathrm{~m}$ depth and shows an increase in density from 8-9 to 12-13 sigma-t and an increase in salinity from $12-13$ psu to c. 15 psu. The second inhomogeneous layer extends down to 10 metres. Salinity increases from c. 15 psu to c. 25-26 psu and density increases from c. 12-13 sigma-t to c. 20-21 sigma-t. The second homogeneous layer extends from 10 to $35 \mathrm{~m}$. Salinity increases from c. $25-26$ psu to c. 31 psu, and density from c. 20-21 sigma-t to c. 24 sigma-t. In this series, there are little differences between the stations 1-16. There is no clear difference between the salinity- and density-profiles of stations 1-16 and the reference stations $17-19$. However, temperature is $1-2^{\circ} \mathrm{C}$ higher in the depth interval $10-30 \mathrm{~m}$ for all the reference stations. These high temperatures are not related to water discharging from the Vangen power station, because there were no discharges in that period.

\section{Discussion}

\section{Fracture network and groundwater flow}

Phyllitic rocks have, in general, a low primary permeability. From a geomechanical point of view they are incompetent rocks with a tendency to yield by plastic flow and shearing rather than by fracturing when subjected to deformation. Fault zones in such rocks often have an impermeable character (UNESCO, 1984; Sausgruber \& Brandner, 2003). From a hydrogeological viewpoint, an incompetent rock develops few joints with a low ability to maintain wide fracture openings at depths. This is demonstrated by the normally low well yields in phyllitic rocks and mica schists in Norway (Gundersen \& de Beer, 2009), unless they are located in special structural settings (Henriksen, 1995). Such settings may be that of slopes undergoing active DSGSD-deformation, like the slope in Flåm. Although overall fracture connectivity and permeability within independent rock-blocks of phyllite may be low, fractures that separate the low-permeable rock-blocks can provide pathways for groundwater flow to progressively deeper levels.

The hydrogeological model proposed in the following (Fig. 11) relies on the hydrogeological and structural field mapping, the hydrochemical characteristics of the waters, and existing structural and geomechanical models of the rock-slope failure system (e.g., Braathen et al., 2004; Böhme et al., 2013). In general, three subvertical joint sets, some of which are tensional, and a gently fjordward-dipping foliation (Figs.5A \& 11) make up the potential fracture network available for downward percolation of surface water and further saturated groundwater flow. Böhme et al. (2013) incorporated these structures into a discontinuum block-toppling model where steep joints, some of which are open and others with shear displacements, dip into the slope. This is essentially similar to the domino style, complex field model proposed by Braathen et al. (2004). The high electrical conductivity of the discharging groundwater (Table 2) indicates a considerable travel time in shear fractures and faults accompanied by dissolution of minerals like calcite and pyrite. This could be explained by a stepwise network for groundwater flow, wherein open tension fractures, foliation surfaces and reverse block-toppling faults like those depicted by Böhme et al. (2013) are important elements. Such a fracture network, similar to that observed at the outcrop scale (Fig. 5B), would be capable of routing recharging groundwater to 

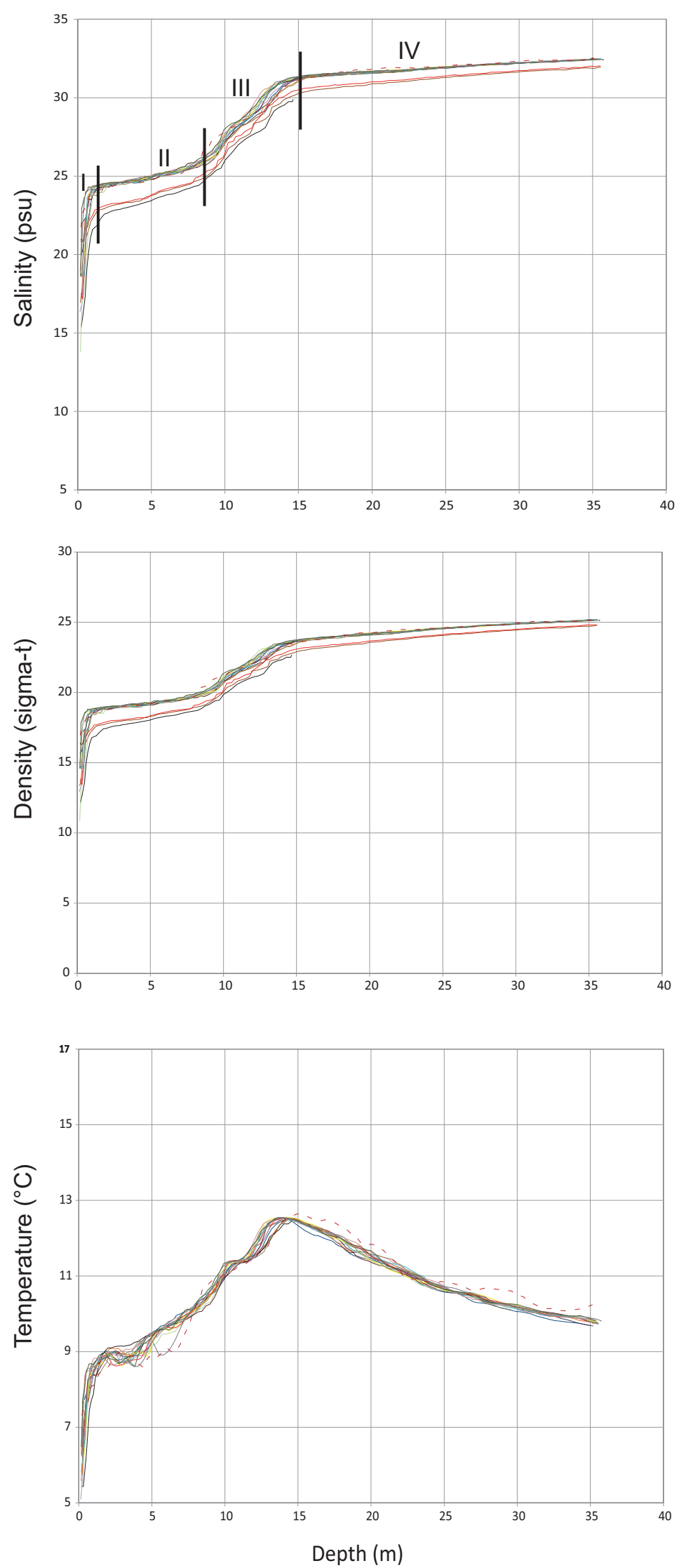

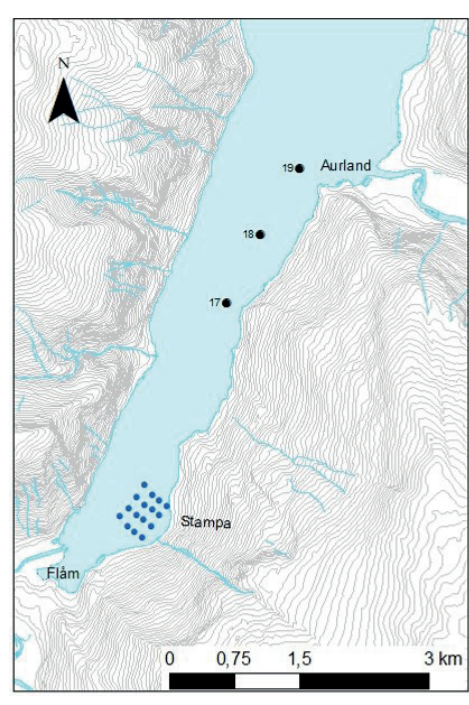

Station 1

Station2

Station 3

Station 4

Station 5

Station 6

Station 7

Station 8

Station 9

Station 10

Station 11

Station 12

Station 13

Station 14

Station 15

Station 16

Station 17

Figure 8. Salinity, density and temperature measurements recorded by stations in the fjord for measuring series 2, 26 November 2013. The density measurements illustrate the typical layered structure of the water mass in the fjord. A freshwater/brackish water layer (I), a homogeneous layer (II), an inhomogeneous layer (III) and a new homogeneous layer (IV) are clearly distinguished. Reference station 17 is the southernmost of the three reference stations on the inset map. 

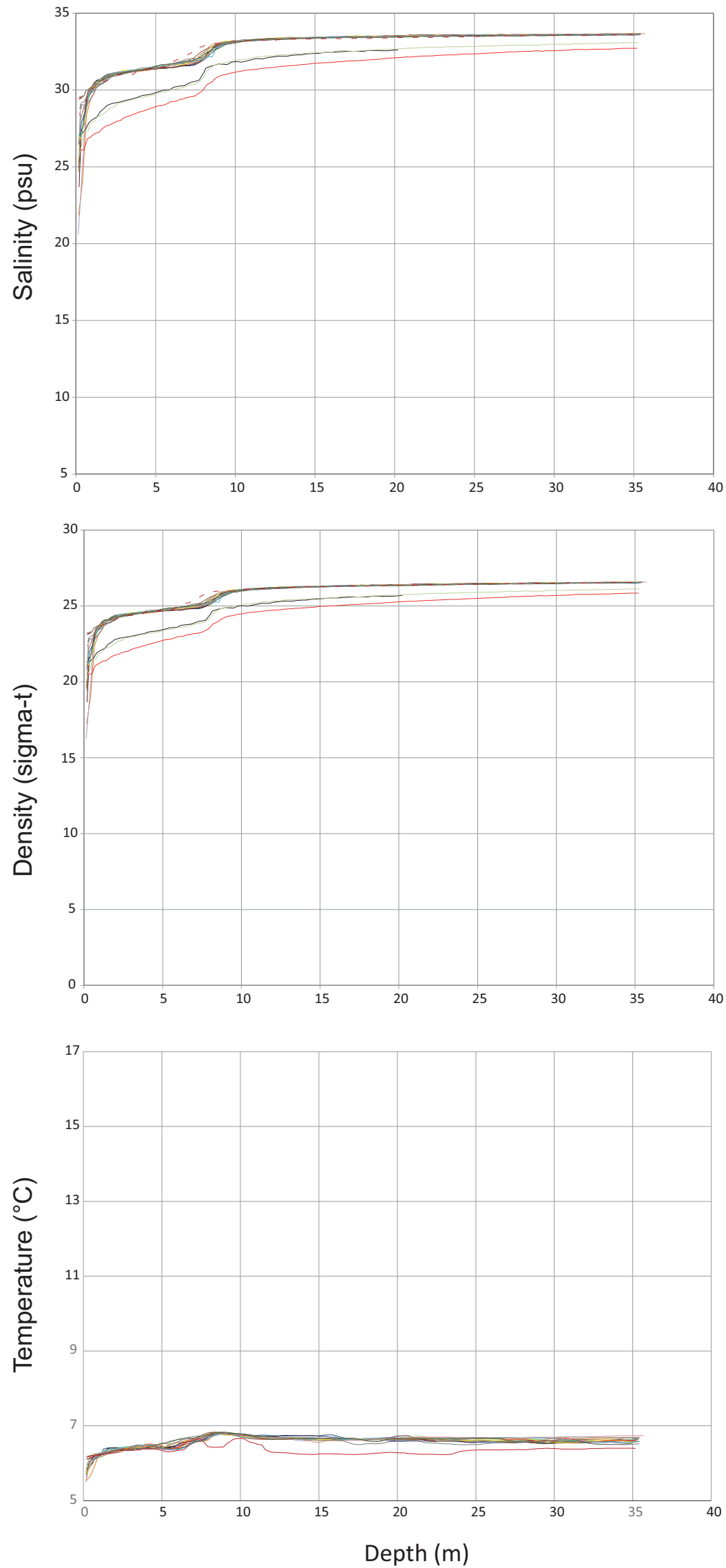

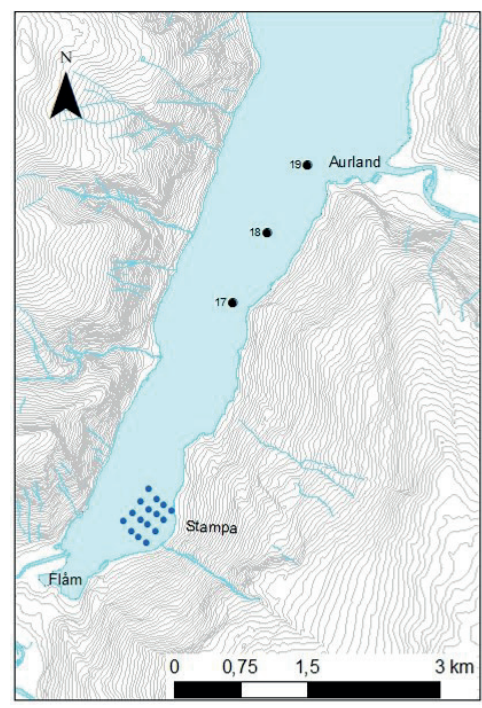

Station 1

Station 2

Station 3

Station 4

Station 5

Station 6

Station 7

Station 8

Station 9

Station 10

Station 11

Station 12

Station 13

Station 14

Station 15

Station 16

Station 17

Figure 9. Salinity, density and temperature measurements recorded by stations in the fjord for measuring series, 7 March 2014. For all layers, stations 4, 9 and 11 have clearly lower values for salinity and density. Reference station 17 is the southernmost of the three reference stations on the inset map. 

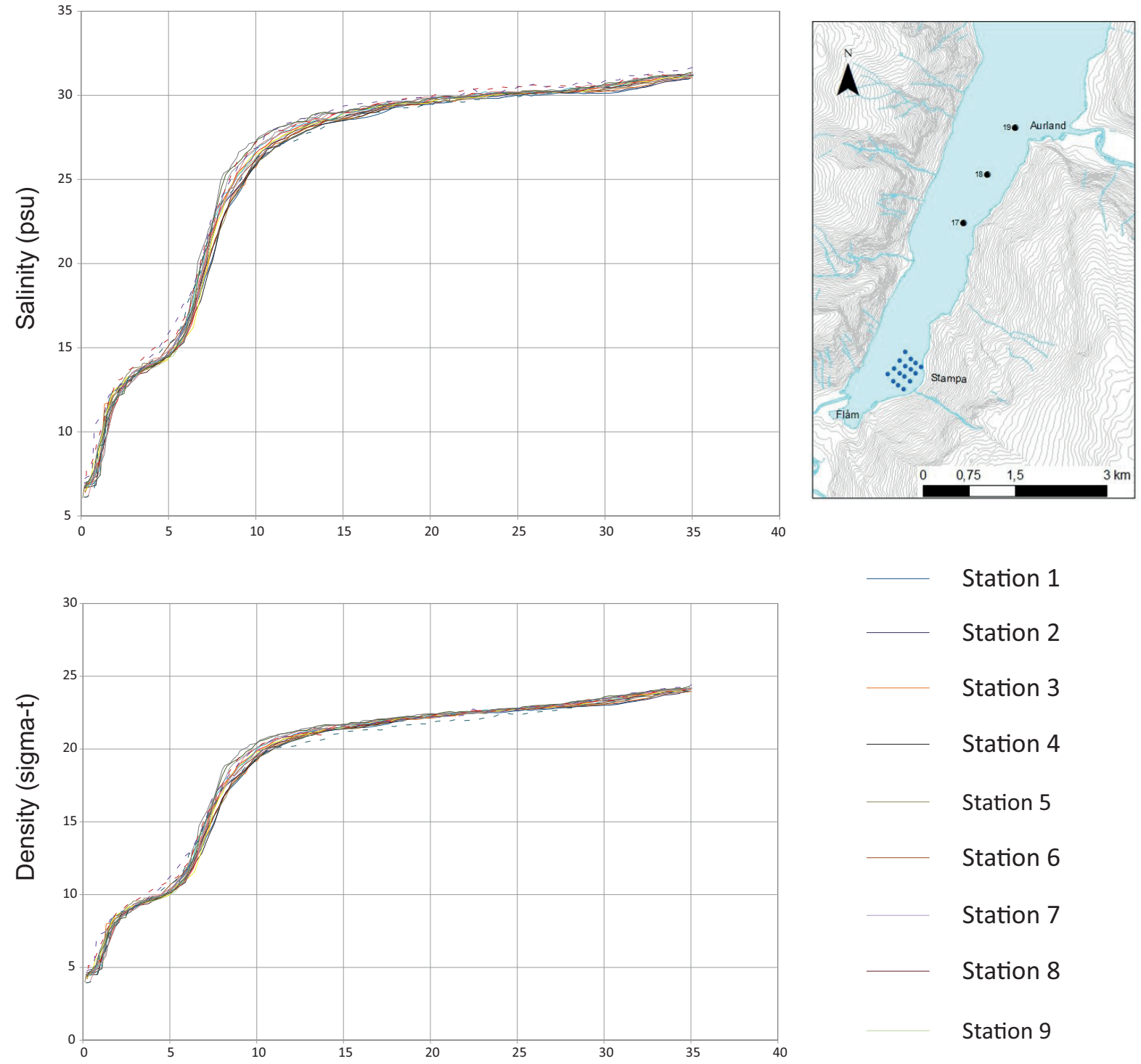

Station 1

Station 2

Station 3

Station 4

Station 5

Station 6

Station 7

Station 8

Station 9

Station 10

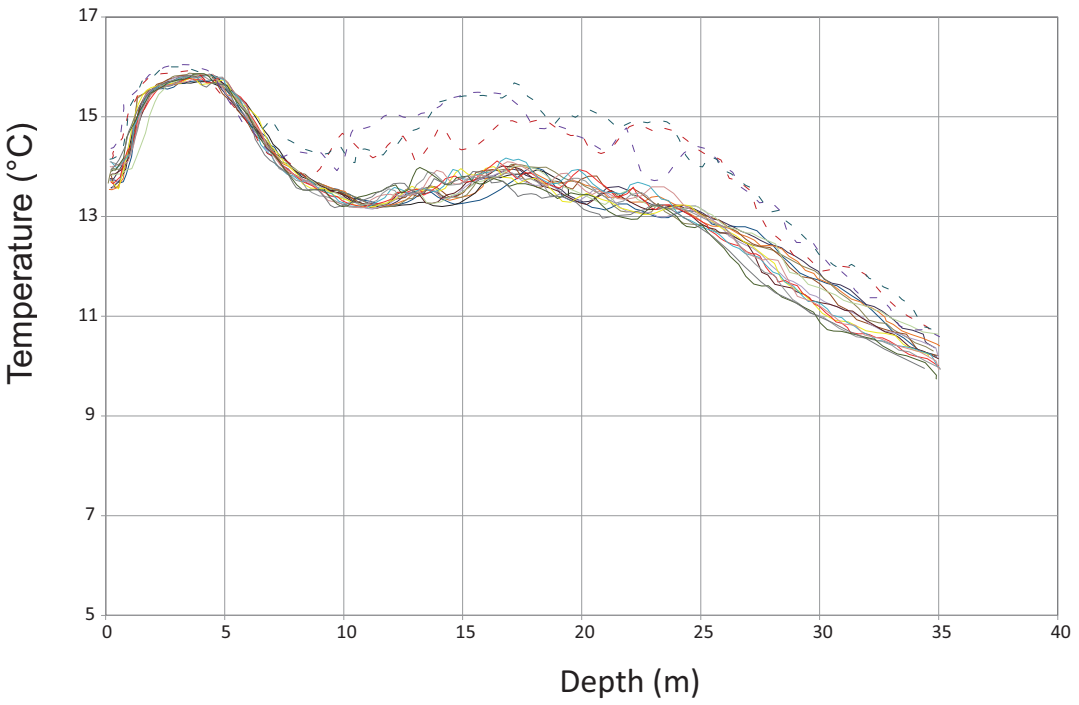

Station 11

Station 12

Station 13

Station 14

Station 15

Station 16

Station 17

Station 18

Station 19

Figure 10. Salinity, density and temperature measurements recorded by stations in the fjord for measuring series 4, 17 August 2014. The profilegraphs for salinity and density are almost identical for stations 1-16 and the reference stations 17-19, while the temperature profiles from the reference stations differ from those of stations 1-16. Reference station 19 is the northernmost of the three reference stations on the inset map. 


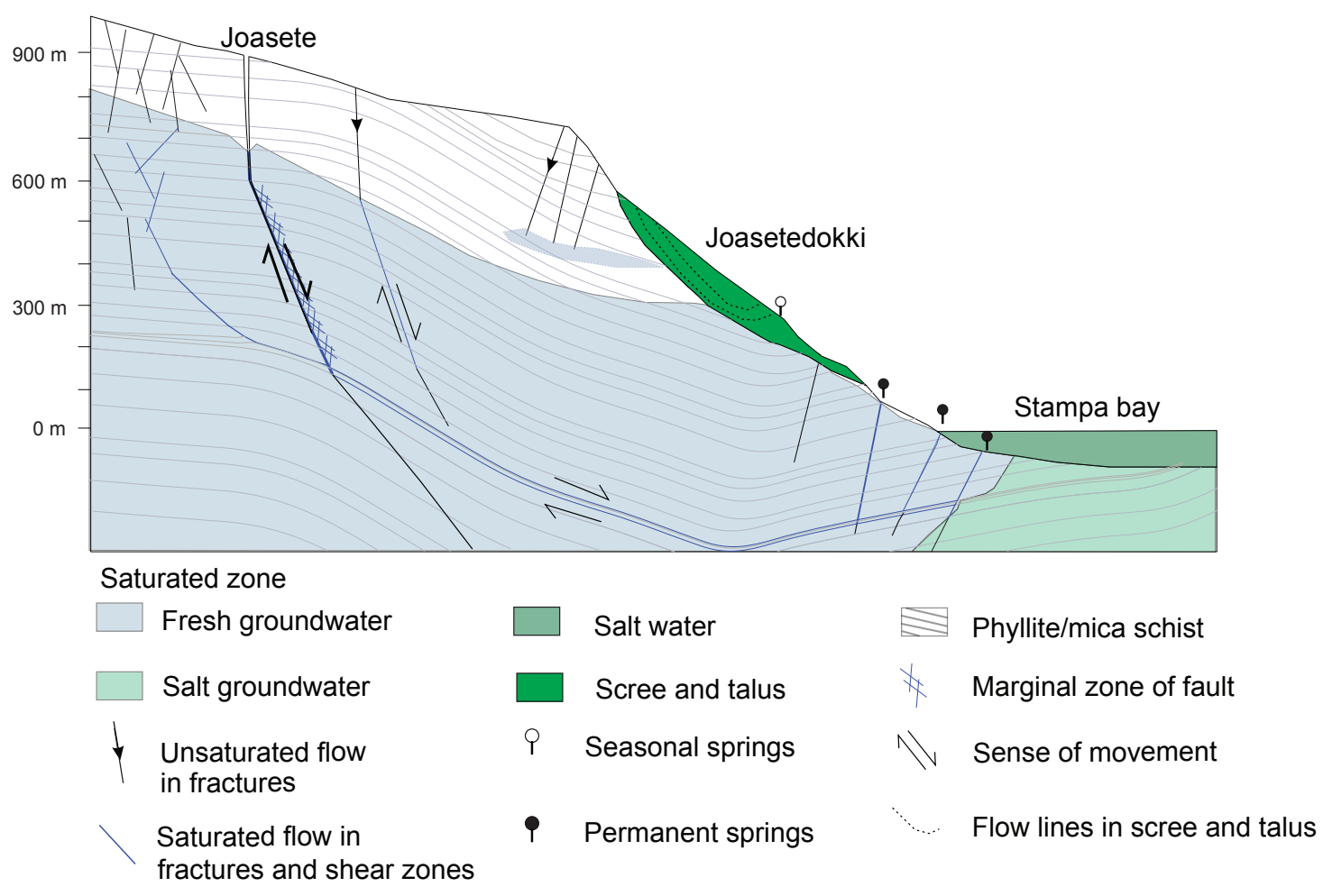

Figure 11. Field-based hydrogeological model of fracture network and groundwater flow in the mountain slope above the fjord at Stampa bay. The model integrates the results and observations from the hydrogeological and structural work between Joasete and Stampa bay from this study and in part from earlier studies. The foliation surface of the phyllite is subhorizontal on the plateau by Joasete. In the road section and slope above Stampa bay it dips at a shallow angle into the mountain slope or is subhorizontal. In between, the foliation has a variable orientation. The model depicts groundwater flow along sheared foliation surfaces a nd/or west-dipping shear zones. In the discharge zone, groundwater is routed along shear-zones, foliation and steeply dipping joints. The model is simplified to outline the main features.

progressively greater depths in the rock mass. Moreover, northwest-facing shear folds and west-dipping shear fractures that reactivate the foliation are commonly observed in the field. These structures, which may relate to Devonian/Permian extensional reworking, may have a role as flow paths for groundwater and in linking up foliation-parallel flow paths. The spring at Bøen (Fig. 4B) appears to discharge along such a fracture.

In addition, it can be argued that vertical tension joints may change into normal faults with depth. The maximum depth before such joints change into normal faults or shear fractures is given by $\mathrm{d}_{\max }=3 \mathrm{~T}_{0} / \rho_{\mathrm{r}}$ (Gudmundsson, 1999; Gudmundsson et al., 2003). Here, $\mathrm{T}_{0}$ is the in situ tensional strength $(\mathrm{MPa}), \rho_{\mathrm{r}}$ is the in situ rock density $\left(\mathrm{kgm}^{-3}\right)$ and $\mathrm{g}$ is the acceleration due to gravity $\left(\mathrm{kgms}^{-2}\right)$. In the upper part of the crust, $\rho_{\mathrm{r}}$ may be taken as approximately $2,300 \mathrm{kgm}^{-3}$ and $\mathrm{T}_{0}$ may range from 1 to $6 \mathrm{MPa}$ (Gudmundsson, 1999). Applying these values to the equation above, a maximum depth of 130-800 metres before a tension fracture would change into a normal fault is obtained. Hence, pre-existing discontinuities could have their continuation as fjordward-dipping normal faults with depth. In the southern part of the area, the back-bounding structure is a west-dipping normal fault with a 1-2 m high scarp (Fig. 2) (Braathen et al., 2004). So far, it has not been possible to identify any clear indications of downward movements associated with the slope-parallel tension joints on the plateau at Joasete and similar joints at lower altitude levels in the unstable slope (Fig. 2).

Normal faults linked with tensional joints at higher levels are important structures for groundwater flow in the upper, decompressed area of unstable slopes (e.g., Binet et al., 2007; Blikra \& Christiansen, 2014; Cappa et al., 2014). However, due to the general high dips of normal faults, around $60^{\circ}$, compared with the dip of the slope, these faults do not necessarily represent sliding planes for a future rockslide. However, they can be important pathways for routing groundwater flow to deeper levels in the slope because the hanging wall damage-zone of normal faults often has enhanced fracture permeability (Braathen \& Gabrielsen, 1998).

That groundwater discharges from springs at different levels in the mountain slope indicates the dependence of groundwater flow on fracture geometry, but also probably seasonal variations in recharge of the surface water. Groundwater that discharges at high levels might reinfiltrate into the scree-deposits farther down and emanate as springs at still lower levels. Deep groundwater flows with longer transit times will have the highest electrical conductivity. Such flow paths may 
have discharge at the fjord bottom. The surface water that recharges into the open cleft at Joasete is considered to have a deep flow path with possible discharge points on the fjord bottom. Some of the non-recharging water together with precipitation recharges the scree deposits about 200 metres lower and has shallower flow paths that give rise to springs faurther down in the mountain slope above the fjord. We consider that the grouping into two distinct populations is related to differences in flow paths and residence time. Population 2 represents groundwater with longer residence times and with flow paths in rock fractures and in the overlying scree deposits.

\section{Fjord bottom discharge}

The hydrostatic equilibrium between fresh and salt groundwater is described by the Ghyben-Herzberg relation (e.g., Cooper, 1964), which states that the height of the fresh groundwater $(\mathrm{z})$ below sea level is 35-40 times the height of the water table (h) above sea level. The Ghyben-Herzberg relation is a simplified relationship, which unrealistically assumes the thickness of the freshwater zone at the shore to be zero and the presence of a sharp boundary between the fresh groundwater and the salt water. However, in order for groundwater to discharge, the freshwater zone must have some thickness seawards away from the shoreline. Fig. 12, based on Cooper (1964), shows a general and more realistic picture of groundwater discharge in the coastal zone. In Fig. 11, the same situation is illustrated for the fractured aquifer in the unstable slope above the fjord.

In the transition zone (Fig. 12), discharging groundwater mixes with saline groundwater and seawater by mechanical dispersion and diffusion. We consider that the seaward extent of the transition zone, where groundwater discharges to the fjord bottom in the study area, may change in space and time caused by variations in the onshore geological structures, tidal cycles and seasonal variations in groundwater recharge rates. We also suspected that the pressure heads of the groundwater in the slope above the fjord would depend on the recharge from the fracture zone at Joasete; and hence affect the position of the transition zone and the degree of mixing with the saline fjord water. Hydraulic heads (h) measured in two boreholes near Otternes, 9. January 2017, indicate the dependence of hydraulic head on local geological structures. Borehole 1, located in bedrock had an hydraulic head of c. $15 \mathrm{~m}$, while borehole 2 located in permeable scree deposits c. $20 \mathrm{~m}$ from the shoreline had a hydraulic head of $1 \mathrm{~m}$. This indicates a depth of c. $40 \mathrm{~m}$ to the freshwater-saltwater interface at that time.

According to Table 2, the discharging fresh groundwater has a low salinity (about $250 \mu \mathrm{s} / \mathrm{cm}$ or $0.2 \mathrm{psu}$ ) compared with the seawater in the fjord (about 32-34 psu at 30 $\mathrm{m}$ depth). The analyses of salinity and density for the 16 stations were on several occasions markedly lower at stations 4, 6, 9, 11 and 16 for the entire water column (e.g., Fig. 8). The analysis of temperature showed no clear differences between the 16 stations. This suggests that the reduced density is largely caused by a reduction in salinity. This is compatible with upstreaming groundwater from the fjord bottom beneath the abovementioned stations that gradually mixes with the in situ salt water up through the water column, causing these stations to have depth profiles with markedly lower salinity and density values.

The four measurement series do not show identical patterns, but are rather time-dependent (Fig. 13). The time variation of the observed pattern could have several reasons. Firstly, the submarine springs can be periodic reflecting variations in surface recharge and transit time. Secondly, tidal currents, estuarine and intermediate circulation will vary from time to time and could be involved in such variations. Station 6 and 11 are neighbouring stations, so are also stations 9 and 16 .

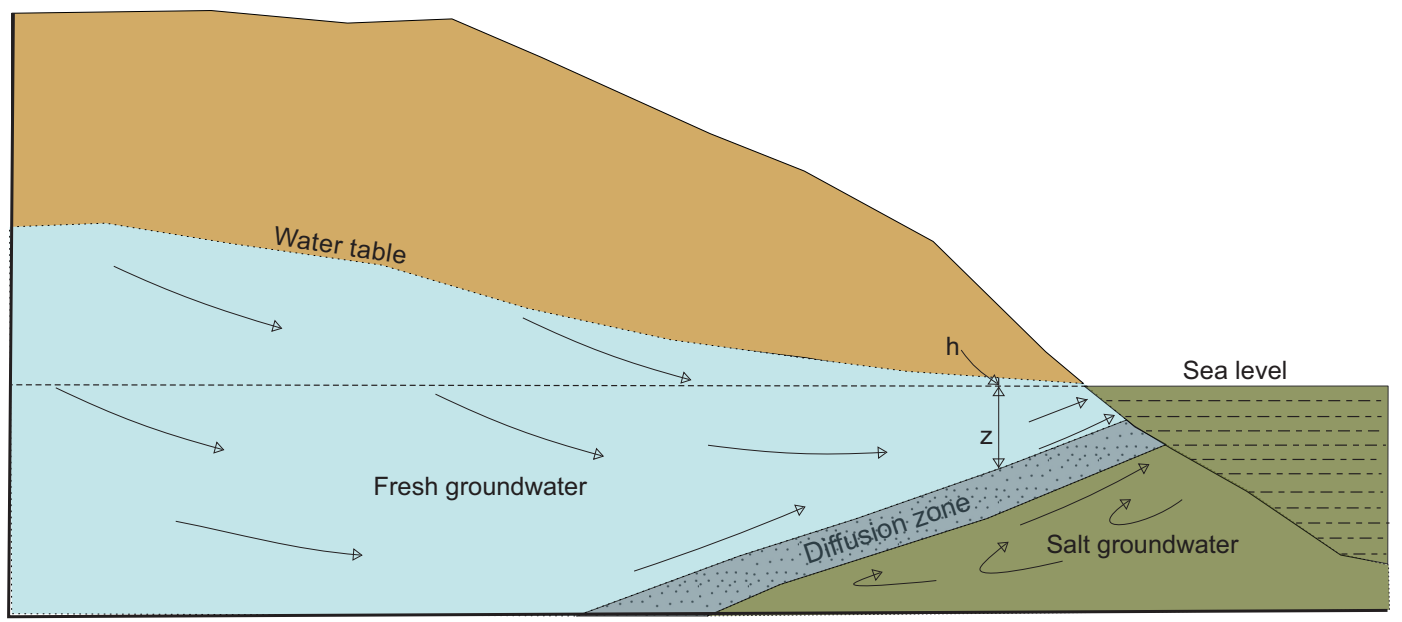

Figure 12. General model of groundwater flow in a coastal zone with permeable soils. Based on Cooper Jr. (1964). 

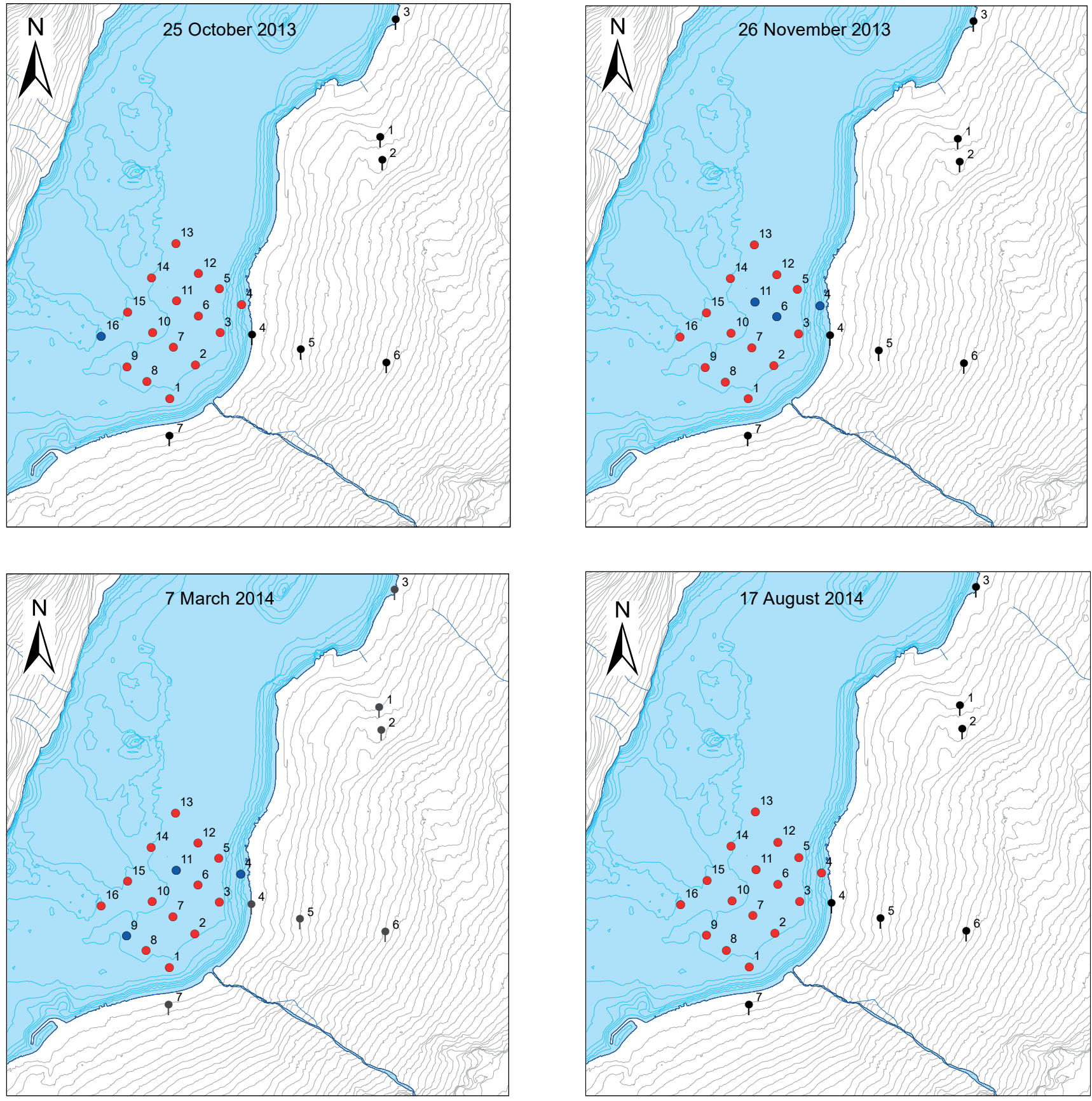

\section{Legend}

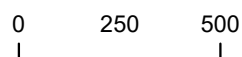

$1000 \mathrm{~m}$

- Onland springs

- Measuring grid in Stampa bay

- Groundwater discharge points in measuring grid

Figure 13. Interpreted submarine groundwater springs and seeps and onland springs during the periods of the four measuring series. Stations with submarine groundwater discharge are marked with dark blue symbols. The density/salinity values for the two pairs of measuring points (6, 11) and $(9,16)$ could result from upwelling of groundwater from two different discharge sources on the fjord bottom located between each of the pairs of points. 
The varying observations for the pair of neighbouring stations could be explained by different transport direction in the surrounding water masses, causing the signals of the upstreaming groundwater to be recorded at station 9 or 16, or at station 6 and 11. Probably, the springs are not located directly below the two pairs of stations, but rather between them. Nevertheless, our measurements suggest upstreaming of freshwater on 25 October 2013 (station 16); 26 November 2013 (stations 4, 6 and 11); and 7 March 2014 (stations 4, 9 and 11). These stations form a diagonal within the grid pointing to three springs at stations 4, 6, 11, 9 and 16. Near station 4, local people have observed movements in the water surface indicative of upstreaming freshwater.

Physical and chemical signatures from discharge points on the fjord bottom could be disturbed by other sources of fresh water, i.e., the river Markåna, the Flåm River, greywater from the cruise traffic and the freshwater outlet from the Vangen power plant at 19-25 m depth (McClimans, 1981) in Aurland. We consider the discharge of fresh water from Markåni and the Flåm River to affect only the upper layer of freshwater/brackish water and not the water at greater depths where most of our measurements were taken. Moreover, the discharge from Markåni was surveyed on a daily basis with an outdoor time-lapse camera and was substantial only in August 2014. Around our measuring series 1 (25 October 2013) and series 2 (26 November) the discharges were negligible, and around the times of our third measuring series (7 March 2014) Markåni was not discharging at all. The inner part of the Aurlandsfjord is narrow, and in the tourist season a number of large and smaller cruise ships arrive and depart Flåm harbour almost every day. The action of propellers and possibly effluents of greywater from the cruise ships could affect the layering of the water mass in the upper 10-20 m of the water column. However, the only measurement series that could be affected by cruise traffic is the series from 17 August. The other measurement series were outside the tourist season.

Except from the series 17 August, the power plant discharge in Aurland was active during all our measuring series. However, investigations in February-March 1981 (McClimans, 1981) showed that the storage depth of the freshwater in the same period was from 1-7 $\mathrm{m}$ depth, with a concentration at c. $4 \mathrm{~m}$ depth. It is therefore considered very unlikely that our measurements are affected by the discharge from the power plant. This is supported by our measurements from three reference stations (17-19) farther out in the Aurlandsfjord. The salinity and density profiles from these stations show only insignificant differences from the measuring stations 1-16 in the Stampa bay.

It could be argued that the reduced salinity is an error caused by air bubbles trapped in the measuring electrode, because air bubbles are produced by the discharging of the exhaust from the outboard engine of the boat, but this does not explain the depth profile of salinity from 25 October. However, since the reduced salinity is only recorded at some stations $(4,6 / 11$ and $9 / 16)$ and at different times, there is a strong indication that the observed patterns are real.

It was suspected that signals from springs on the fjord bottom should appear as distinct layers with different salinity and temperature at given depths like that described for discharges of sewage (Oug et al., 1991) or submerged discharges of freshwater (McClimans, 1981; Ellingsen et al., 2006). The signals we found, however, appeared more or less in the entire water column. Such a situation, with lower density (c. 1 sigma-t) in some stations and in the entire water column from 0 to $35 \mathrm{~m}$, can probably only be maintained by a constant rise of freshwater gradually mixing with the adjacent salt water. In addition to its effect on water composition, submarine discharge of groundwater (SGD) may also affect the seabed topography. The effect of SGD on the subsurface morphology depends on the size and structure of the spring outlet and amount of discharge. Seepage from a spring horizon can be as a distributed flow that affects only the water composition, whereas focused discharge may also affect the subsurface morphology. In such areas, SGD discharge points may be associated with pockmarks in the sediments above (e.g., Reusch et al., 2015). Webb et al. (2009) described an area with more than 500 depressions in the Oslofjord, which they interpret as inactive and active pockmarks.

The alignment of the signals from rising groundwater along a diagonal in the grid indicates that the discharge points 4, 6, 9 and 16 represent small groundwater seeps along a NE-SW fracture, like the spring in Bøen (Fig. 4B), rather than focused groundwater outlets with high discharge. This is supported by the relatively small potential groundwater discharge, $0-4.1 \mathrm{l} / \mathrm{s}$, on the fjord bottom. The lack of correlation between submarine groundwater discharge points in Stampa bay and pockmarks is attributed to distributed seepage rather than focused discharge. In addition, debris flows in 1950, 1979 and 1986 (The Norwegian Road Authority, 1979; Sandersen, 1986), which had runouts into the fjord basins, may have buried existing pockmarks in this area.

\section{Water balance and groundwater flow from mountain to fiord}

In our model, surface water infiltrates into the main open cleft at Joasete and the catchment above and distributes farther into a heterogeneous fracture system as shown in Fig. 11. The total average recharge may vary between 5.7 and $16.1 \mathrm{l} / \mathrm{s}$ (Table 3). The discharge from the springs in the mountain slope varies between $5.9 \mathrm{l} / \mathrm{s}$ and $12.5 \mathrm{l} / \mathrm{s}$. The potential fjord bottom discharge, calculated as the 
Table 3. Summary table with key parameters relating to the water balance.

\begin{tabular}{lc}
\hline Recharge & \\
\hline Recharge to bedrock in catchment $(1 / \mathrm{s})$ & $0.5-9.1$ \\
Recharge to bedrock through open fracture $(1 / \mathrm{s})$ & $5.2-7$ \\
\hline Total recharge $(1 / \mathrm{s})$ & $5.7-16.1$ \\
\hline Discharge & $5.9-12$ \\
\hline Onland discharge from springs $(1 / \mathrm{s})$ & $0-4.1$ \\
\hline Potential fjord bottom discharge $(1 / \mathrm{s})$ & $5.9-16.1$ \\
\hline Total discharge $(1 / \mathrm{s})$
\end{tabular}

difference between the total recharge and the onland spring discharge, would be between $01 / \mathrm{s}$ and $4.1 \mathrm{l} / \mathrm{s}$.

During short-duration storm-water episodes, with combined snowmelt and precipitation, the recharge to the open fracture at Joasete alone may be as high as $21 \mathrm{l} / \mathrm{s}$. The high discharge from springs in the hillslope for about two weeks in May-June (Fig. 4C, D) probably relates to such an episode. The electrical conductivity of the discharging groundwater was only slightly reduced, which indicates that a large amount of groundwater was driven out of the fracture system at that time. This can be explained by a temporary higher hydraulic gradient in the slope and/or wider apertures in the water-conducting fractures, because volumetric water flow $(\mathrm{Q})$ according to Darcy's law (equation 2) is proportional to hydraulic gradient (i) and cross-sectional area (A) of water flow:

$\mathrm{Q}\left(\mathrm{m}^{3} / \mathrm{s}\right)=\mathrm{k}(\mathrm{m} / \mathrm{s}) \cdot \mathrm{i} \cdot \mathrm{A}\left(\mathrm{m}^{2}\right)$

Here, $\mathrm{k}$ is a constant of proportionality termed hydraulic conductivity.

Preliminary results from data logging show that the water level in the drilled well close to spring one at Otternes rose $10 \mathrm{~m}$ during 24 hours at about the same time as the high spring discharge (Soldal et al., 2017; B. Soldal pers. comm. 2018). A likely cause for this could be an abrupt change (increase) in fracture aperture causing higher inflow rates to the well. This seasonal variation in groundwater pressure is comparable with the rockslope breathing process detected by InSAR analyses of the Mannen/Børa rockslope in the Romsdalen valley (Rouyet et al., 2017).

\section{Groundwater transit times}

Because of the heterogeneity of the fracture network, calculation of groundwater transit times is an extremely difficult task. It could be evaluated by natural tracers like oxygen isotopes or temperature, or by different artificial tracers. The approach in this work has been to compare, in time and space, the variation in groundwater recharge with variations in groundwater discharge from the points in the fjord bottom in 2013-2014. Discharging groundwater from springs on the fjord bottom is considered to have deep flow paths with long transit times and to be little affected by precipitation that infiltrates in the mountain slope above the fjord. Our recordings of recharge into the open cleft at Joasete through the year show that groundwater recharge to the fracture network takes place in the period c. 15 May to c. 20 November, disrupted only by short periods with little or no precipitation. From c. 20 November to c. 15 May, Joasetegrovi is dry and frozen down and there is no groundwater recharge. Fjord bottom discharge is recorded 25 October 2013, 26 November 2013, 7 March 2014 but not 17 August 2014 (Fig. 13). Since there was no recharge after 20 November 2013 but discharge at the fjord bottom 7 March 2014, this would indicate a transit time of minimum 108 days. The lack of any recordable fjord-bottom discharge 17 August 2014 is explained by the surface water recharging the fracture system on the plateau from c. 15 May 2014 had not reached the discharge points on the fjord bottom at that time. This gives a minimum transit time of c. 96 days. If the pattern in 2013 is taken to represent the conditions in 2014, a maximum transit time of 165 days is found because seabottom discharge was recorded 26 October. Transit times for groundwater during extreme storm-water and snowmelting periods with high groundwater recharge could be shorter than this. Judged by information provided by local people, it could be as low as one week.

\section{Groundwater flow and rock-slope stability}

The available structural and hydrogeological data give no clear and unequivocal answer to how groundwater flows in the unstable mountain slope and its effect on slope stability. The mapping of onland springs indicates that there are no permanent springs at higher levels than about $300 \mathrm{~m}$ above the fjord, which indicates that scenarios with toe lines above this level are partly or completely drained. This has some consequences for the risk evaluation of scenarios $2 \mathrm{a}, 2 \mathrm{~b}, 3 \mathrm{a}$ and $3 \mathrm{c}$. However, the existence of non-permanent or perched aquifers in the rock blocks defining these scenarios (i.e., Fig. 11) cannot be excluded. This may result in destabilisation due to water pressure in periods of snowmelt and strong precipitation. The high electrical conductivity of the groundwater discharging at elevations less than c. $300 \mathrm{~m}$ a.s.l. suggests ongoing chemical dissolution of minerals in fractures along the flow paths. This can have consequences for the long-term stability of scenarios 1a and $1 \mathrm{~b}$. Rapid fluctuations in groundwater levels and discharge like that observed in spring 1 at Otternes and in the adjacent borehole indicate that the fracture system is periodically stressed by opening and closing of fracture apertures. This process could also affect the stability of the rock slope in the longer term. 


\section{Conclusions and future work}

This paper is the first work that deals with the groundwater flow in the unstable mountain slope below Joasete and summarises the results of low-cost measurements carried out during the period 2010-2017.

i. The hydrogeological and hydrographical investigations point to the presence of at least six springs in the mountain slope beneath Joasete and three springs on the fjord bottom that have their main recharge from the small stream Joasetegrovi where it flows across the back-bounding fracture of the unstable rock slope.

ii. The recharge to the rock mass varies considerably throughout the year, with an average recharge of 5.7-16.1 $1 / \mathrm{s}$ from the recharge zone in the open fracture at Joasete and the catchment above. There are considerable uncertainties regarding the values for direct recharge to the bedrock outside the open fracture. Nevertheless, it is considered likely that the total discharge from the springs in the mountain slope and on the fjord bottom balance the amount of river recharge in the suspected release area of the unstable slope.

iii. Depending on season, the submarine groundwater discharge on the fjord bottom may be from $0 \mathrm{l} / \mathrm{s}$ to $4.1 \mathrm{l} / \mathrm{s}$.

iv. A method in which time variation in groundwater recharge is compared with variation in submarine groundwater discharge indicates transit times of minimum c. 96 days and maximum 165 days for the longest flow-paths in the fracture network of the unstable rock slope. The springs at higher altitudes have generally shorter transit times and may have flow paths in the fractured rock mass and in the overlying scree deposits. During storm-water episodes in combination with snowmelt transit times may be considerably shorter.

v. So far, no permanent groundwater discharge above c. $300 \mathrm{~m}$ above sea level have been observed, which indicates that the rock mass in the slope is well drained above this level. Since groundwater pressure will lower the shear strength of a failure surface, this observation is important for the stability conditions of the fracture systems above this level.

vi. The high electrical conductivity of the discharging groundwater suggests ongoing chemical dissolution of minerals along fracture and/or foliation planes. This may affect the long-term stability of scenario 1 .

vii. Storm-water and meltwater episodes in the catchment stress the fracture system in the slope below by repetitive widening and closing of the fracture apertures.

Investigations are presently being conducted to obtain a further understanding of the hydrogeological system in the slope. They include the application of environmental isotopes to obtain information on groundwater flow paths and transit times, more accurate recharge/discharge data and hydrochemical studies. In the longer term, the abrupt and seasonal changes in hydraulic heads should be compared with satellite based InSAR data or groundbased monitoring to identify whether these changes are coeval with vertical displacements in the slope.

Acknowledgements. The work was sponsored by Aurland municipality (2010) and by The Norwegian Water Resources and Energy Directorate (2013-2015). We also thank Oddmund Soldal and Stein Bondevik for critical comments on the report that forms the basis of this paper, and Alvar Braathen for comments on the first draft of the manuscript. The authors sincerely thank the two reviewers for their improvements of the manuscript.

\section{References}

Agliardi, F., Crosta, G. \& Zanchi, A. 2001: Structural constraints on deep-seated slope deformation kinematics. Engineering Geology 59, 83-102. https://doi.org/10.1016/S0013-7952(00)00066-1.

Binet, S., Guglielmi, Y., Bertrandet, C. \& Mudry, J. 2007: Unstable rock slope hydrogeology: insights from the large-scale study of western Argentera-Mercantour hillslopes (South-East France). Bulletin de la Société Géologique de France 178, 159-168.

https://doi.org/10.2113/gssgfbull.178.2.159.

Blikra, L.H \& Christiansen, H.H. 2014: A field-based model of permafrost-controlled rockslide deformation in northern Norway. Geomorphology 208, 34-49.

https://doi.org/10.1016/j.geomorph.2013.11.014.

Blikra, L.H., Longva, O., Braathen, A., Anda, E., Dehls, J.F. \& Stalsberg, K. 2006: Rock Slope Failures in Norwegian Fjord Areas: Examples, Spatial Distribution and Temporal Pattern. In Evans, S.G., Scarascia Mugnozza, G., A. Strom \& R.L. Hermanns (eds.): Landslides from Massive Rock Slope Failure, NATO Science Series IV, Earth and Environmental Sciences Volume 49, Springer, Dodrecht, Netherlands, pp. 475-496.

https://doi.org/10.1007/978-1-4020-4037-5_26.

Bogaard, T., Guglielmi, Y., Marc, V., Emblanch, C., Catherine Bertrand, C. \& Mudry, J. 2007:

Hydrogeochemistry in landslide research: a review. Bulletin de la Société Géologique de France 178, 113-126.

https://doi.org/10.2113/gssgfbull.178.2.113.

Braathen, A. \& Gabrielsen, R.H. 1998: Lineament architecture and fracture distribution in metamorphic and sedimentary rocks, with application to Norway. NGU Report 98.043, 78 pp.

Braathen, A., Blikra, L.H., Berg, S.S. \& Karlsen, F. 2004: Rock-slope failures of Norway; type, geometry, deformation mechanisms and stability. Norwegian Journal of Geology 84, 67-88. 
Brenne, E., Ellingsen, S. \& Nes, S. 2011: Vannførings og georadarundersøkelser på Joasete, Aurland kommune. Bachelor Thesis, Sogn og Fjordane University College, 99 pp.

Burnett, W.C., Aggarwal, P.K., Aurel, A., Bokuniewicz, H., Cable, J.E., Charette, M.A., Kontar, E., Krupa, S., Kulkarni, K.M., Loveless, A., Moore, W.S., Oberdorfer, J.A., Oliveira, J., Ozyurt, N., Povinec, P., Privitera, A.M.G., Rajar, R., Ramessur, R.T., Scolten, J., Stieglitz, T., Tanniguchi, M. \& Turner, J.V. 2006: Quantifying submarine groundwater discharge in the coastal zone via multiple methods. Science of the Total Environment 367, 498-543. https://doi.org/10.1016/j.scitotenv.2006.05.009.

Bøe, R., Lepland, A., Blikra, L.H., Longva, O. \& Sønstegaard, E. 2002: Postglacial mass movements in western Norway with special emphasis on the 2000-2200 BP and 2800-3200 BP periods - final report. NGU Report 2002.020, 114 pp.

Bøe, R., Longva, O., Lepland, A., Blikra, L.H., Sønstegaard, E., Haflidason, H., Bryn, P. \& Lien, R. 2004: Postglacial mass movements and their causes in fjords and lakes in western Norway. Norwegian Journal of Geology 84, 35-55.

Böhme, M., Saintot, A., Henderson, I.A.C., Henriksen, H. \& Hermanns, R.L. 2011: Rock slope instabilities in Sogn og Fjordane County, Norway: a detailed structural and geomorphological analysis. In Jaboyedoff, M. (ed.): Slope tectonics, Geological Society of London Special Publication 351, pp. 97-111.

Böhme, M., Hermanns, R.L., Oppikofer, T., Fischer, L., Bunkholt, H.S.S., Eiken, T., Pedrazzini, A., Derron, M.H., Jaboyedoff, M., Blikra, L.H. \& Nilsen B. 2013: Analyzing complex rock slope deformation at Stampa, western Norway, by integrating geomorphology, kinematics and numerical modeling. Engineering Geology 154, 116-130. https://doi.org/10.1016/j.enggeo.2012.11.016.

Cappa, F., Guglielmi, Y., Soukatchoff, V.M., Mudry, J., Bertrand, C. \& Charmoille, C. 2004: Hydromechanical modeling of a large moving rock slope inferred from slope levelling coupled to spring long-term hydrochemical monitoring: example of the La Clapiére landslide (Southern Alps, France). Journal of Hydrology 291, 67-90. https://doi.org/10.1016/j.jhydrol.2003.12.013.

Cooper Jr., H.H. 1964: A hypothesis concerning the dynamic balance of fresh water and salt water in a coastal aquifer. In Cooper, H.H., Kohout, F.A., Henry, H.R. \& Glover, R.E. (eds.): Sea water in coastal aquifers. Relation of salt water to fresh ground water. U.S. Geological Survey Water-Supply Paper 1613-C, C1-C12.

Domaas, U., Rosenvold, B.S., Blikra, L.H., Johansen, H., Grimstad, E., Sørlie, J.E., Gunleiksrud, O., Engen, A. \& Lægreid, O. 2002: Studie av fjellskred og dalsidestabilitet i fyllittområder. NFR Report 20001132-2, 146 pp.

ECO vannkraft 2009a: Vardeskredbekken går tørr. https://www.youtube.com/watch?v=r84oS5fEWik, MP4-video accessed 29.06.2009.

Ellingsen, I.H., Slagstad, D. Tangen, K. \& Reitan, K.I. 2006: Modellering av effekter av neddykket utslipp på det lokale fysiske og biologiske miljøet i Gaupnefjorden og Lustrafjorden. SINTEF Report SFH80 FO 62625, 20 pp.

Farmer, D.M. \& Freeland, H.J. 1983: The Physical Oceanography of Fjords. Progress in Oceanography 12, 147-219.

https://doi.org/10.1016/0079-6611(83)90004-6.

Furseth, A. 2006: Skredulykker i Norge. Tun Forlag, Oslo, 207 pp.
Ganerød, G.V., Grøneng, G., Rønning, J.S., Dalsegg, E., Elvebakk, H., Tønnesen, J.F., Kveldsvik, V., Eiken, T., Blikra, L.H. \& Braathen, A. 2008: Geological model of the Åknes rockslide, western Norway. Engineering Geology 102, 1-18.

https://doi.org/10.1016/j.enggeo.2008.01.018.

Geoteam AS 1979: Seismiske målinger ved Otreneset, RV. 601. Geoteam Report 5943.01, 5 pp.

Grøneng, G., Christiansen, H.C., Nilsen, B. \& Blikra, L.H. 2011: Meteorological effects on seasonal displacements of the Åknes rockslide, western Norway. Landslides 8, 1-15. https://doi.org/10.1007/s10346-010-0224-x.

Gudmundsson, A. 1999: Postglacial crustal doming, stresses and fracture formation with application to Norway. Tectonophysics 307, 407-419. https://doi.org/10.1016/S0040-1951(99)00107-9.

Gudmundsson, A., Gjesdal, O., Brenner, S.L. \& Fjeldskaar, I. 2003: Effects of linking up of discontinuities on fracture growth and groundwater transport. Hydrogeology Journal 11, 84-99. https://doi.org/10.1007/s10040-002-0238-0.

Guglielmi, Y., Cappa, F. \& Binet, S. 2005: Coupling between hydrogeology and deformation of mountainous rock slopes: Insights from La Clapière area (southern Alps, France). Comptes Rendus Geoscience 337, 1154-1163. https://doi.org/10.1016/j.crte.2005.04.016.

Gundersen, P. \& de Beer, H. 2009: Statistikk vanngiverevne i forskjellige bergarter. ForForUT deloppgave 3. Statusrapport 2009. NGU Report 2009.066, 9 pp.

Henriksen, H. 1995: Relation between Topography and Well Yield in Boreholes in Crystalline Rocks, Sogn og Fjordane, Norway. Ground Water 33, 635-643. https://doi.org/10.1111/j.1745-6584.1995.tb00319.x.

Henriksen, H. \& Dale, T. 2016: Grunnvannsutsrømning på fjordbunnen fra sprekkesystemet i den ustabile fjellsiden ved Stampa, Aurlandsfjorden, Sogn og Fjordane. Sogn og Fjordane University College Report 2/16, Sogndal, 35 pp.

Hermanns, R.L., Bunkholt, H., Boehme, M., Fischer, L., Oppikofer, T., Rønning, J.R. \& Eiken, T. 2011: Foreløpig fare- og risikovurdering av ustabile fjellparti ved Joasete-Furekamben-Ramnanosi, Aurland kommune. NGU Report 2011.025, 46 pp.

Hughes, A.L.C., Gyllencreutz, R., Lohne, Ø.S., Mangerud, J. \& Svendsen, J.I. 2015: DATED-1: compilation of dates and time-slice reconstruction of the build-up and retreat of the last Eurasian (British-Irish, Scandinavian, Svalbard-Barents-Kara Seas) Ice Sheets 40-10 ka. Department of Earth Science, University of Bergen and Bjerknes Centre for Climate Research, PANGAEA.

Klakegg, O., Nordahl-Olsen, T., Sønstegaard, E. \& Aa, R. 1989: Sogn og Fordane fylke kvartærgeologisk kart, scale 1:250,000, Norges geologiske undersøkelse.

Knutsson, G. \& Morfeldt, C.O. 2002: Grundvatten. Teori \& tillämpning. AB Svensk byggtjänst, Stockholm, $227 \mathrm{pp}$.

Mangerud, J., Gyllencreutz, R., Lohne, Ø. \& Svendsen, J. 2011. Glacial History of Norway. Developments in Quaternary Science 15, 279298. https://doi.org/10.1016/B978-0-444-53447-7.00022-2.

McClimans, T.A. 1981: Dykket utslipp fra Vangen kraftverk. Etterprøving. SINTEF Report STF60 F81113.

McClimans, T.A., Eidnes, G. \& Aure, J. 2002: Controlled artificial upwelling in a fjord using a submerged fresh water discharge: computer and laboratory simulations. Hydrobiologica 484, 191-202. https://doi.org/10.1023/A:1021369408346. 
Merz, J. \& Doppmann, G. 2006: Measuring Mountain Stream Discharge Using the Salt Dilution Method. A practical Guide. PARDYP/ ICIMOD and Hydrology group, University of Bern, 15 pp.

NGI 2008: Utredning av ustabile dalsider i fyllitt. Aurland. NGI Report 20081254-1, 33 pp.

NGU 2018: Nasjonal database for ustabile fjellparti. http://geo.ngu.no/kart/ustabilefjellparti, accessed 18 January 2018.

NVE 2002: Avrenningskart for Norge. Årsmiddelverdier for avrenning 1961-1990. NVE Report 2-2002, 48 pp.

NVE 2013: The unstable phyllitic rocks in Stampa- Flåm, western Norway. Compilation, scenarios, risk and recommendations. NVE Report 35-2013, 55 pp.

Oug, E., Molvær, J., Moy, F. \& Næs, K. 1991: Resipientundersøkelse i fjordområdet ved Farsund. Vannusskiftning, vannkvalitet, strandsoneregistreringer og bløtbunnsfauna. NIVA Report O-90187-2661, 65 pp.

Reusch, A., Loher, M., Bouffard, D., Moernaut, J., Hellmich, F., Anselmetti, F.S., Bernasconi, S.M., Hilbe, M., Kopf, A.J., Lilley, M.D., Meinecke, G. \& Strasser, M. 2015: Giant lacustrine pockmarks with subaqueous groundwater discharge and subsurface sediment mobilization. Geophysical Research Letters 42, 3465-3473.

https://doi.org/10.1002/2015GL064179.

Rouyet, L., Kristensen, L., Derron, M-C., Michoud, C., Blikra, L.H, Jaboyedoff, M. \& Lauknes, T.R. 2017: Evidence of rock slope breathing using ground-based InSAR. Geomorphology 289, 152169. https://doi.org/10.1016/j.geomorph.2016.07.005.

Saintot, A., Henderson, I.H.C. \& Derron, M-C. 2011: Inheritance of ductile and brittle structures in the development of large slope instabilities: examples from western Norway. In Jaboyedoff, M. (ed.): Slope tectonics, Geological Society of London Special Publication 351, pp. 27-78. https://doi.org/10.1144/SP351.3.

Saito, M., Guo, X., Onodera, S., Shimizu, Y., Yoshiaki, K., Tokumasu, M. \& Takeoka, H. 2011: Spatial variation of Submarine Groundwater discharge (SGD) in the Central Part of Seto Inland Sea, Japan. In Omori, K., Guo, X., Yoshie, N., Fujii, N., Handoh, I.C., Isobe A. \& Tanabe S. (eds): Interdisciplinary Studies on Environmental Chemistry, Marine Environmental Modeling \& Analysis, Terrapub, 117-123.

Sandersen, F. 1986: RV.601- Flåm-Aurland. Vurdering av fare for flomskred i Markåna, og forslag til sikring. NGI Report 85474-1, 7 pp.

Sausgruber, T. \& Brandner, R. 2003: The Relevance of Brittle Fault Zones in Tunnel Construction - Lower Inn Valley Feeder Line North of the Brenner Base Tunnel, Tyrol, Austria. Mitteilungen der Österreichischen Geologischen Gesellschaft 94, 157-172.

Singhal, B.B.S. \& Gupta, R.P. 1999: Applied Hydrogeology of Fractured Rocks. Kluwer Academic Publishers, Dordrecht/Boston/London, 400 pp. https://doi.org/10.1007/978-94-015-9208-6.

Soldal, B., Henriksen, H. \& Skoglund, R.Ø. 2017: Hydrogeologiske undersøkelser av det ustabile fjellpartiet Joasete-Otternes i Flåm, Aurland kommune. Abstract Geofaredagen 2017, NGI Oslo.

The Norwegian Road Authority 1979: Rasfarlig ur ved Otreneset, RV 601, Fretheim-Aurland. Veglaboratoriet Report 930-C, 10 pp.

Thorne, G.A. \& Gascoyne, M. 1993: Groundwater recharge and discharge characteristics in granitic terranes of the Canadian shield. Memoires of the XXIVth Congress of International Association of Hydrogeologists, Ås, Oslo, 368-374.

UNESCO 1984: Ground water in hard rocks. Studies and reports in hydrology 33, UNESCO Paris, 228 pp.
Webb, K.E., Hammer, Ø. Lepland, A. \& Gray, J.S. 2009: Pockmarks in the inner Oslofjord, Norway. Geo-Marine Letters 29, 111-124. https://doi.org/10.1007/s00367-008-0127-1. 